\title{
Renewable Energy Prices in State-Level Feed-in Tariffs: Federal Law Constraints and Possible Solutions
}

Scott Hempling National Regulatory Research Institute Silver Spring, Maryland

Carolyn Elefant The Law Offices of Carolyn Elefant Washington, D.C.

Karlynn Cory National Renewable Energy Laboratory Golden, Colorado

Kevin Porter Exeter Associates, Inc. Golden, Colorado

Technical Report NREL/TP-6A2-47408 January 2010 


\section{Renewable Energy Prices in State-Level Feed-in Tariffs: Federal Law Constraints and Possible Solutions}

\section{Technical Report NREL/TP-6A2-47408 January 2010}

Scott Hempling

National Regulatory Research Institute

Silver Spring, Maryland

Carolyn Elefant

The Law Offices of Carolyn Elefant

Washington, D.C.

Karlynn Cory

National Renewable Energy Laboratory

Golden, Colorado

Kevin Porter

Exeter Associates, Inc.

Golden, Colorado

Prepared under Task No. PVC9.9720

National Renewable Energy Laboratory

1617 Cole Boulevard, Golden, Colorado 80401-3393

303-275-3000 • www.nrel.gov

NREL is a national laboratory of the U.S. Department of Energy

Office of Energy Efficiency and Renewable Energy

Operated by the Alliance for Sustainable Energy, LLC

Contract No. DE-AC36-08-GO28308

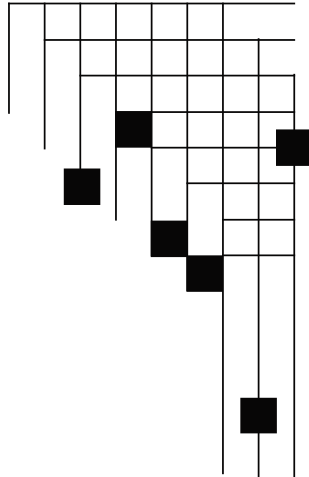




\section{NOTICE}

This report was prepared as an account of work sponsored by an agency of the United States government. Neither the United States government nor any agency thereof, nor any of their employees, makes any warranty, express or implied, or assumes any legal liability or responsibility for the accuracy, completeness, or usefulness of any information, apparatus, product, or process disclosed, or represents that its use would not infringe privately owned rights. Reference herein to any specific commercial product, process, or service by trade name, trademark, manufacturer, or otherwise does not necessarily constitute or imply its endorsement, recommendation, or favoring by the United States government or any agency thereof. The views and opinions of authors expressed herein do not necessarily state or reflect those of the United States government or any agency thereof.

Available electronically at http://www.osti.gov/bridge

Available for a processing fee to U.S. Department of Energy and its contractors, in paper, from:

U.S. Department of Energy

Office of Scientific and Technical Information

P.O. Box 62

Oak Ridge, TN 37831-0062

phone: 865.576 .8401

fax: 865.576 .5728

email: mailto:reports@adonis.osti.gov

Available for sale to the public, in paper, from:

U.S. Department of Commerce

National Technical Information Service

5285 Port Royal Road

Springfield, VA 22161

phone: 800.553 .6847

fax: 703.605.6900

email: orders@ntis.fedworld.gov

online ordering: http://www.ntis.gov/ordering.htm 


\section{Acknowledgments}

This work was funded by two programs of the U.S. Department of Energy's (DOE) Energy Efficiency and Renewable Energy (EERE) Division. Therefore, the authors wish to thank participating staff - Charles Hemmeline of the DOE and Jennifer DeCesaro of Sentech from the EERE Solar Program, and David Rodgers and Carla Frisch from the EERE Strategic Policy and Analysis Program - for providing useful insights and overall direction to this project. The authors are also grateful for the guidance and helpful input of the project managers, Robert Margolis, Selya Price, Gian Porro, and Thomas Schneider of the National Renewable Energy Laboratory (NREL).

We would also like to thank the individuals who reviewed various drafts of this report, particularly James Newcomb, David Kline, Claire Kreycik and David Hurlbut of NREL; Elaine Ulrich of the U.S. DOE; Jennifer DeCesaro of Sentech; Lawrence R. Greenfield of the Federal Energy Regulatory Commission; Robert C. Grace of Sustainable Energy Advantage; Chad Laurent and Wilson Rickerson of Meister Consultants Group; Jason Keyes, Joseph Wiedman, and Kevin Fox of the law firm Keyes and Fox; and Ed McNamara and Kurt Janson of the Vermont Public Service Board. Finally, we are grateful to Mike Meshek of NREL for providing important editorial support.

This report reflects the views of its authors only. It does not necessarily reflect the positions of NRRI or any of its funders, constituents, or clients. 


\section{Executive Summary}

\section{The Need for Guidance to States}

State legislatures and state utility commissions seeking to attract renewable energy projects are considering arrangements called "feed-in tariffs." These tariffs would obligate retail utilities to purchase electricity from renewable producers under standard arrangements specifying prices, terms and conditions. This standardization simplifies the purchase process, provides revenue certainty to generators, and reduces the cost of financing generating projects.

States decision makers have encountered arguments that state-level feed-in tariffs are preempted by federal law. These arguments arise because the transaction resulting from a feedin tariff is a wholesale sale of electricity, from renewable seller to retail utility. A wholesale sale of electricity triggers one of two federal statutes - the Public Utility Regulatory Policies Act of 1978 (PURPA) or the Federal Power Act of 1935 (FPA). Each of these statutes does in fact limit the discretion of state-level tariff designers.

State utility commissions, in conjunction with the National Association of Regulatory Utility Commissioners (NARUC), asked the National Renewable Energy Laboratory (NREL) to explore how states can lawfully implement feed-in tariffs. In response to that request, NREL hired the National Regulatory Research Institute (NRRI) to be the lead author of this report and to provide the needed legal expertise. NREL participated as a coauthor to clarify the current renewable energy policy and markets. This report seeks to reduce the legal uncertainties for states contemplating feed-in tariffs by explaining the constraints imposed by federal statutes. This report describes the federal constraints, identifies certain transaction categories that are free of those constraints, and offers ways for state and federal policymakers to interpret or modify existing law to remove or reduce these constraints. This report explains options for how these federal statutes could be revised.

There is no standard, official definition of "feed-in tariff." To facilitate a full vetting of federal legal constraints that state lawmakers ${ }^{1}$ must address, this report creates a broad working definition of "state-level feed-in tariff", as follows:

a publicly available, legal document, promulgated by a state utility regulatory commission or through legislation, which obligates an electric distribution utility to purchase electricity from an eligible renewable energy seller at specified prices (set sufficiently high to attract to the state the types and quantities of renewable energy desired by the state) for a specified duration; and which, conversely, entitles the seller to sell to the utility, at those prices for

${ }^{1}$ While this report focuses on state-level feed-in tariffs, municipally owned power systems (most of which are not regulated by state commissions) can also offer these tariffs. These are briefly mentioned in the introduction. 
that duration, without the seller needing to obtain additional regulatory permission. $^{2}$

Given this definition, this report comes to the following conclusions: There are paths to non-preempted, state-level feed-in tariffs under current federal law. Each "current law" path falls into one of three categories, involving varying levels of certainty and effort:

1. Paths that are available now, with no further action necessary by the Federal Energy Regulatory Commission (FERC);

2. Paths that would become available if FERC clarified or modified its precedents; and

3. Paths that would become available if FERC issued new rules, declaratory orders or both, to create safe harbors, rebuttable presumptions, or other guidance that rendered state-set tariff prices lawful under the FPA.

Additional paths are possible if Congress amends PURPA or the FPA to remove or reduce existing statutory constraints. Detailed discussions involving states, FERC, renewable producers, utility buyers, and possibly Congress will be necessary to create a legal context in which states can enact or promulgate feed-in tariffs as defined above.

\section{Constraints and Solutions}

The definition of feed-in tariff (FIT) used here assumes that the tariff is the result of a legal mandate - either by statute directly or by commission direction as authorized by statute. A state wishing to create that mandate has two options. First, the state can rely on the utility's purchase obligations under PURPA, shaping the state-level requirements to satisfy PURPA's constraints. Sellers under this approach need not comply with the Federal Power Act. Second, the state can rely on a state statutory mandate independent of PURPA. Sellers under this approach must comply with the Federal Power Act, unless FERC has exempted them. A brief explanation of each alternative follows.

2 The phrase "feed-in tariff" originated with European measures in which the term "feedin" referred to the renewable producer's right to interconnect with the utility and thus "feed in" its output to the electric grid. This report focuses on the pricing of power, not on interconnection, because it is the pricing issue that raises specific concerns about constraints of federal law on state decision making. This report also assumes that while a state's legislature may have directed the utilities commission to establish tariffs, that legislation will vest the responsibility for creating and administering the tariffs with the state utility commission. 


\section{Public Utilities Regulatory Policies Act}

Since 1978, PURPA has offered certain renewable energy producers and cogenerators a way to require utilities to purchase their output. The seller first must receive FERC certification as a "qualifying facility" (QF). (FERC rules limit this certification to a subset of renewable energy technologies and project sizes.) $\mathrm{A} Q \mathrm{QF}$ is exempt from most FPA price regulation (see "Federal Power Act" below), but its pricing still is constrained: it can sell only at a price (a) established or approved by the state commission or (b) reached through negotiation with the utility. That price, if mandated by the state, cannot exceed the utility's "avoided cost." (Prices negotiated with the utility can exceed avoided cost.) Avoided cost is the cost the utility would have incurred had it self-supplied, or bought from a third party, the products and services (such as capacity and energy) it is buying from the QF. The problem for state-level feed-in tariff designers is that a utility's avoided cost is likely to be lower than the price necessary to attract and sustain the renewable seller.

For states relying on the PURPA mandate, certain feed-in tariffs are possible without any action by FERC or Congress. Currently, a state implements PURPA by establishing an avoided cost price, which the utility must offer to QFs. FERC precedent allows states to supplement this avoided cost payment (i.e., get the QF compensation exceeding avoided cost), in one of three ways: (a) assigning "renewable energy credits,"3 (b) making cash grants or paying production-based incentives (funded, for example, by taxpayers through the general budget, or by ratepayers through a "system benefits charge"), or (c) establishing a purchase price that exceeds avoided cost but granting the purchasing utility a tax credit equal to the excess. FERC has found that these forms of supplemental compensation fall outside of its PURPA jurisdiction, and therefore are not preempted. This PURPA mandate path is available to QFs of any size, but it is not available if the seller is not a $Q F{ }^{4}$

Problem: Utilities now can seek exemption from the PURPA purchase requirement. Under PURPA amendments enacted in 2005, FERC has exempted some utilities from their PURPA obligation to buy power from QFs with capacities greater than $20 \mathrm{MW}$. If states with jurisdiction over these utilities wish to establish feed-in tariffs, they will have to create a mandate under state law; and the sellers will need to comply with the Federal Power Act, as discussed next.

${ }^{3}$ As discussed later in this report, renewable energy certificate (REC) market prices may vary across regions and across time, raising questions about their effectiveness in drawing draw long-term investment for renewable energy projects.

${ }^{4}$ In other words, the power producer must apply to FERC to be certified as a QF. 


\section{Federal Power Act}

Since 1935, the Federal Power Act has placed in FERC (previously the Federal Power Commission) the exclusive authority to regulate "the sale of electric energy at wholesale in interstate commerce." The Federal Power Act is a contract-based statute. It is unlawful to make a sale at wholesale without a contract, and without FERC approval of that wholesale contract. Put more directly, a state-level tariff cannot lawfully command the utility to purchase at the state-set price. Under Sections 205 or 206 of the FPA, the seller must prove to FERC, that the contract, including its price, is "just and reasonable" and not "unduly discriminatory." To receive FERC approval, the wholesale seller must choose one of two procedures:

"Cost-based rates": The seller signs a contract with the utility buyer, then submits that contract to FERC for review. FERC establishes a public proceeding to review the seller's cost data (which the seller must make public). FERC must determine that the contract price recovers no more than prudent costs plus a reasonable return on equity. The process applies on a contract-by-contract basis.

"Market-based rates": Instead of seeking approval contract-by-contract, the seller seeks from FERC a blanket approval to enter contracts at will, at whatever price the seller and buyer negotiate. To gain FERC's approval, the seller must submit a detailed technical study proving that it has no "market power," i.e., no ability to set and sustain prices above competitive (i.e., "just and reasonable") levels, in the markets in which the seller intends to sell. (FERC does not require state-by-state studies, just studies addressing the geographic areas in which the seller will sell.) The seller must repeat the market-power study every three years, and regularly file other reports, so that FERC can ensure that the seller cannot exercise market power to raise prices above "just and reasonable" levels. A seller with market-based rate authority can enter contracts without additional FERC approval.

Given the FPA's requirements, a state-level feed-in tariff, as defined above, outside of PURPA, is not legally possible in the United States today. It is not possible because the tariff cannot produce a lawful transaction by itself; there must be FERC approval of the contract resulting from the tariff. That approach, of course, differs fundamentally from the Europeanstyle definition of a feed-in tariff (and from the broad definition introduced above), which contemplates a sale resulting from the tariff without the seller needing to obtain any additional regulatory approval. Instead, this modified tariff is only the first step. The authors of this report reason that if the state redefines the tariff as the retail utility's offer to buy, there would be no lawful sale until (a) the utility and the seller enter into a contract and (b) FERC approves that contract. $^{5}$

5 An additional jurisdictional wrinkle pertains. The Federal Power Act requirements do not apply in Hawaii, Alaska, and most of Texas; while PURPA applies throughout the United States (except to the extent FERC has relieved utilities of their PURPA purchase obligation). An explanation of the Hawaii-Alaska-Texas exception appears in the main text. 
But, a clear path to state-level feed-in tariffs, outside of PURPA, would open for small QFs if FERC clarified or modified its precedents: FERC has granted an exemption from Sections 205 and 206 of the FPA for QFs with capacity of $20 \mathrm{MW}$ and below. These QFs are free to sell at wholesale, at any price, without seeking FERC approval. Based on this exemption, the report authors reason that states should be able to establish feed-in tariffs for these small entities consistent with this report's broad definitions. Under these tariffs, the seller could consummate transactions under the state program without any federal involvement or additional steps. Two cautions pertain. First, this path is not available to non-QFs, or QFs exceeding $20 \mathrm{MW}$. Second, FERC would need to modify or reinterpret existing FERC precedent. This precedent states that if the seller is a QF, it is bound by PURPA's avoided cost cap even if the buyer's obligation to buy arises from state law rather than PURPA. With a change to existing FERC precedent, sales by QFs with capacity of $20 \mathrm{MW}$ and less would face no federal constraint on the state-set price.

Another path opens if FERC creates safe harbors, rebuttable presumptions, or other guidance concerning state-set offer prices: One way for FERC to facilitate seller compliance with the FPA is to establish "safe harbors," rebuttable presumptions, or other forms of guidance. Under this approach, FERC would identify criteria or standards concerning the pricing for various technologies, project sizes, and geographic markets. If states designed their tariffs to be consistent with the FERC guidelines, sellers under those tariffs would be deemed by FERC to have complied with the FPA's requirement that prices be "just and reasonable" and not "unduly discriminatory." Because there is no recent FERC experience with this type of approach, an administrative inquiry and rulemaking process (including fact-finding) would be necessary. Actions by FERC can occur through one of the following procedures: FERC can initiate action itself by issuing proposed rulemakings or policy statements; or states and other entities can seek FERC action by filing petitions for rulemaking or requests for declaratory orders. Note that FERC decisions that set different prices for different sellers must have an evidentiary basis (such as cost differences) to withstand an attack that holds that the differences constitute "undue discrimination" prohibited by the FPA.

What if the price a state wishes renewable sellers to receive (in order to attract sufficient quantities) is above these federally mandated levels? As noted above, FERC's PURPA precedent allows states to supplement the avoided cost compensation through renewable energy credits, cash payments, and even prices above avoided cost (if the utility payment receives a state tax credit equaling the increment above avoided cost). This report argues that this same FERC-authorized flexibility is available in the FPA setting.

Retail sales present no preemption problem: Federal law constraints apply only to wholesale transactions. Retail transactions fall outside both federal statutes. States are free to establish programs allowing renewable generators to sell to retail customers. (These programs are not similar to the feed-in tariffs addressed in this report, because they do not create any obligation in the retail customer to buy from the generator). This state freedom includes the situation where a non-utility sells power to a retail customer who is a participant in a net metering program (often called a third-party owned power purchase agreement or third-party owned lease). The retail customer's purchases from the non-utility seller cause the retail 
customer's meter to "run backwards," reducing his purchases from the utility. Provided there is no "net sale" during a billing cycle - a net sale would occur if the retail customer's purchases from the non-utility exceed the customer's usage during a billing cycle-FERC will treat the non-utility generator as making only retail sales, not wholesale sales; thus the FPA will not apply. FERC explained this reasoning in its Declaratory Order in SunEdison, 129 FERC para. 61,146 (Nov. 19, 2009).

\section{Congressional Action}

Congress could modify PURPA and the FPA to allow states to establish feed-in tariffs unconstrained by current federal law. The intent behind such an amendment would be to create exceptions from PURPA, the FPA, or both, for renewables sellers in states that promulgate tariffs having certain characteristics. The result would be to vest in the sellers an automatic right to sell under state programs. This report describes several options in this category.

This report is solely a legal analysis that responds to NARUC's and NREL's requests. It is not an endorsement of state-level feed-in tariffs or of any of the alternative paths or statutory amendments described here. 
Acknowledgments .......................................................................................................................... iii

Executive Summary ................................................................................................ iv

The Need for Guidance to States .......................................................................................... iv

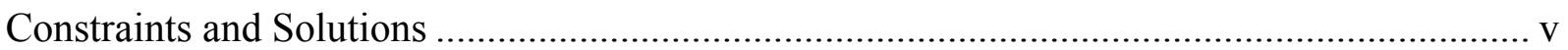

Public Utilities Regulatory Policies Act ............................................................................ vi

Federal Power Act ………........................................................................................ vii

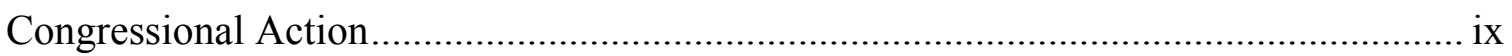

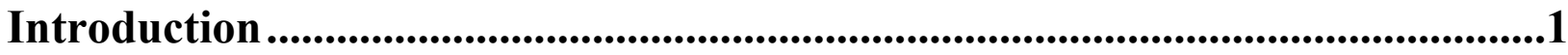

A. Renewable Energy Feed-in Tariffs in Context …….................................................... 1

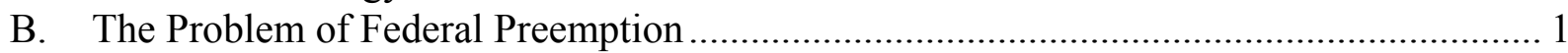

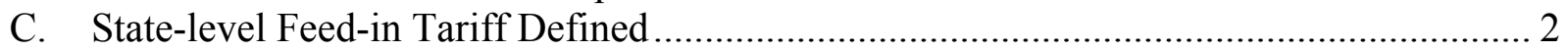

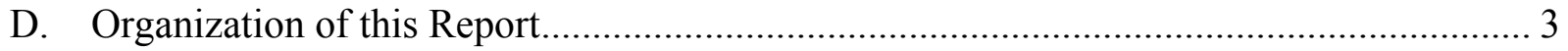

I. State-Level Tariffs Based on a PURPA Mandate ........................................5

A. PURPA Overview: A utility must buy capacity and energy from "qualifying facilities," priced at the utility's avoided cost................................................................................... 5

B. PURPA Administration: FERC grants QF status; states determine avoided cost and

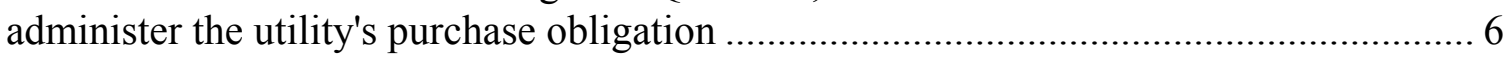

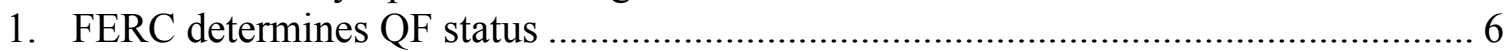

2. State determines the utility's avoided cost.............................................................. 7

C. PURPA Shrinkage: FERC has exempted some utilities from PURPA's purchase

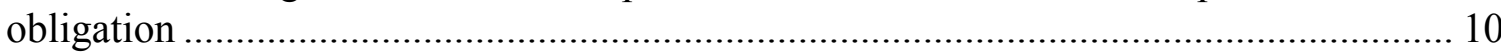

D. Compensation for PURPA Sellers: States can—with care—grant renewable sellers compensation exceeding the utility's avoided cost ......................................................... 13

1. Renewable energy credits awarded to the renewable seller ........................................ 14

2. Tax credits awarded to the utility purchaser ............................................................. 16

3. Payments to the renewable seller from other sources .............................................. 18

4. The problem of avoided cost variability .................................................................... 18

5. Can the state set different PURPA prices for different technologies? ....................... 19

E. Application of PURPA concepts to state feed-in tariffs: Summary of the three steps ..... 19

II. State-Level Tariffs Based on a State Law Mandate .....................................21

A. Federal Power Act Overview: FERC has exclusive jurisdiction to set wholesale rates.. 22

B. To avoid FPA preemption, states must fashion their feed-in tariffs as offers to purchase, but even then legal uncertainty exists ................................................................. 23

1. FPA Background: FERC's preemptive authority over wholesale sales.................... 23

2. State authority to require offers to purchase is not preempted if FERC clarifies or

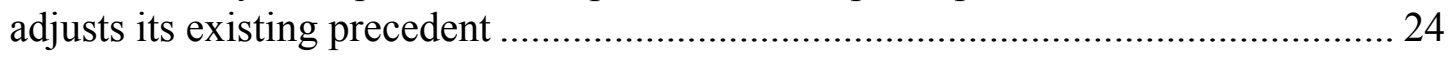

3. FERC preemption precedent needs clarification and/or adjustment ....................... 26

4. Conclusions on the state role in wholesale price-setting.................................... 28 
C. In the FPA context, the state can set different sales offer prices for different

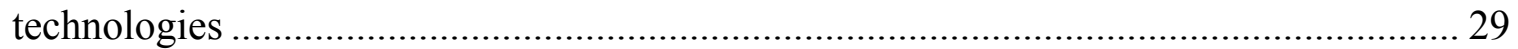

D. Once states establish feed-in tariffs, sellers still must obtain FERC permission to sell... 29

1. Contract-by-contract approval (cost-based rates) ....................................................... 30

2. Blanket advance approval (market-based rates) ………….......................................... 30

3. Supplemental compensation from the state ................................................................ 32

4. Must the seller in a state law-based regime still comply with PURPA's avoided cost

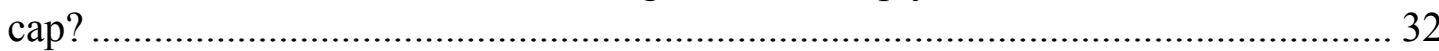

E. Exemptions from FPA review for QFs sized $20 \mathrm{MW}$ and below if FERC clarifies and/or adjusts its precedent ............................................................................................... 36

F. Safe Harbors, Presumptions and other Forms of Guidance: FERC can facilitate sellers' compliance with the Federal Power Act ............................................................................ 37

III. Amendments to Current Federal Statutes...........................................................41

A. The House-Passed American Clean Energy and Security Act ......................................... 41

B. Four Conceptual Federal Legislative Options .................................................................... 43

IV. Related Questions....................................................................................44

A. What price-setting methods are available to state designers of feed-in tariffs? ................ 44

B. Does the applicability of the FPA or PURPA change if the seller's delivery to the buyer occurs at a distribution facility rather than a transmission facility? ................................. 44

C. Do the federal statutes apply to renewable sales to retail customers? ............................... 45

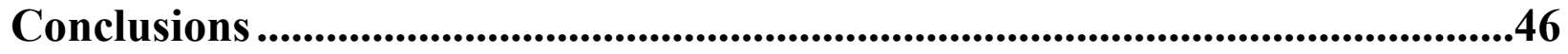

Appendix A: Overview of Preemption Analysis ..........................................................48

Appendix B: PURPA Exemptions and Termination of Mandatory Purchase Provisions - Statutes and Regulations ........................................................................50

\section{List of Figures}

Figure 1. Can a state order its utilities to file "feed-in tariffs"? Two paths to nonpreemption 


\section{Introduction}

\section{A. Renewable Energy Feed-in Tariffs in Context}

The desire to diversify electric generation sources has occupied policymakers since 1978, when Congress passed the Public Utility Regulatory Policies Act (PURPA). Aimed at reducing the nation's dependence on fossil fuels, Section 210 of PURPA ${ }^{6}$ directed retail utilities to purchase capacity and energy from "qualifying facilities," defined as either cogenerators or small non-fossil generators. Since the late 1990s, some states have promulgated renewable portfolio standards (RPS), which require retail utilities to procure a prescribed percentage of their electricity needs from renewable sources. ${ }^{7}$ A third state-level effort is "net metering," which allows a customer's meter to "run backwards" if they self-generate renewable energy.

Many states are now exploring a fourth concept, the "feed-in tariff." As currently used in Europe, this type of tariff creates a continuing obligation in the local utility to buy eligible renewable producers' output at standardized rates typically reflective of generation costs and under standard terms and conditions. As of January 2010, California, Hawaii, Oregon, and Vermont had authorized or required renewable energy feed-in tariff programs. ${ }^{8}$

\section{B. The Problem of Federal Preemption}

By this report's working definition, a state-level feed-in tariff is a mandate- - mandate from the state to the utility to buy wholesale electricity from renewable sellers at standard prices, terms and conditions. States wishing to enact this mandate have encountered legal uncertainty because wholesale sales of electricity are subject to one of two federal statutes: PURPA or the Federal Power Act of 1935 (FPA). Under certain circumstances, each of these federal statutes "preempts" state statutes and regulations. ${ }^{9}$

6 16 U.S.C. sec. $824 a-3$.

${ }^{7}$ Wiser, Ryan and Galen Barbose, 2008. Renewable Portfolio Standards in the United States: A Status Report with Data Through 2007, Lawrence Berkeley National Laboratory technical report LBNL-154E, April. http://eetd.lbl.gov/ea/EMS/reports/lbnl-154e-revised.pdf.

8 "Renewable Energy Tariffs in Europe and Elsewhere," Excel spreadsheet assembled by Paul Gipe to capture tariffs for different technologies in different countries, states and provinces, updated December 2009, found at http://www.wind-

works.org/FeedLaws/RenewableTariffs.xls, accessed December 13, 2009; "Tariff Watch: the latest photovoltaic tariff news from regions worldwide," Photovoltaics International's website "PV Tech," found at http://www.pv-tech.org/tariff_watch/, accessed December 13, 2009; and PHOTON International website, found at www.photon-international.com, accessed December 13, 2009.

9 A short tutorial on preemption appears in Appendix A. 
This report seeks to reduce legal uncertainties for states contemplating feed-in tariffs. This report explains the constraints federal statutes place on state-mandated feed-in tariffs. It then describes actions available to policymakers wishing to create more certain paths for these state initiatives. Those actions fall into the following categories:

1. State legislatures and state commissions can design tariffs within existing federal legal boundaries.

2. On its own, or in response to requests for rulemakings or declaratory orders, the Federal Energy Regulatory Commission (FERC) can (a) clarify its precedents to eliminate certain constraints, and/or (b) create procedures that simplify and standardize renewable sellers' obligations under one or both federal statutes.

3. Congress can amend FPA and/or PURPA to diminish or eliminate certain constraints.

\section{State-level Feed-in Tariff Defined}

There is no standard, official definition of state-level feed-in tariff. This report uses the following definition, designed to illustrate the full range of interactions with federal law:

a publicly available, legal document, promulgated by a state utility regulatory commission or through legislation, which obligates an electric distribution utility to purchase electricity from an eligible renewable energy seller at specified prices (set sufficiently high to attract to the state the types and quantities of renewable energy desired by the state) for a specified duration; and which, conversely, entitles the seller to sell to the utility, at those prices for that duration, without the seller needing to obtain additional regulatory permission.

This broad definition reflects states' wishes both to eliminate the legal uncertainty associated with state rate-setting and to reduce seller and buyer transaction costs (such as cost of FERC filings and proceedings).

While this report focuses on state-level feed-in tariffs, they do not make up the full universe of tariff possibilities. Municipally owned power systems (like municipally owned utilities, most of which are not regulated by state commissions) can offer these tariffs as well. Although municipal power systems are not subject to the Federal Power $\mathrm{Act}^{10}$ and thus can sell power at wholesale outside of FERC jurisdiction, under PURPA

10 Section 201(f) provides:

No provision in this Part [16 U.S.C. sec. 824 et seq.] shall apply to, or be deemed to include, the United States, a State or any political subdivision of a State, or any 
they must act in roles similar to both a state commission (setting mandatory PURPA purchase prices at avoided) and a purchasing utility (obligated to purchase from QFs at avoided cost). ${ }^{11}$ Thus, the analyses in this report apply to municipal power systems similarly to how they apply to state commissions and how they apply to renewable producers. A municipal power system can offer a feed-in tariff, but if that tariff relies on the municipal's PURPA obligation it must comply with FERC's PURPA rules. And if that tariff relies not on the PURPA purchase obligation but on a municipal power system's self obligation to make purchases, or a state-imposed obligation to make purchases, the seller will need address FPA obligations (unless the seller has an exemption from the FPA).

\section{Organization of this Report}

There are, at present, two alternatives paths by which states can implement a feed-in tariff consistently with federal law." Part I explains how the state can rely on the utility's PURPA purchase obligation. Part II describes how states can rely on state law independent of PURPA (but that is still subject to the FPA). In Figure 1 at the end of Part II, the authors provide a single-page summary of the existing path for non-preemption under PURPA and the path for non-preemption under state law (if FERC changes existing precedent).

To understand each path, one must understand how they interrelate. If the state relies on the PURPA option, the sellers must comply with PURPA's "avoided cost" price cap - and compliance will exempt the sellers from rate regulation under the FPA. If, instead, the state relies on state law, this report argues that sellers will be exempt from PURPA's "avoided cost" cap, but FERC precedent does not share this view. (Clarification from FERC, either on its own initiative or in response to a request from states or others, would make this non-PURPA path available with more certainty. FERC will need to revisit and reverse these rulings, either under its own order or by request from a filing party, for exemption via the state law option to take effect.) Sellers who take this route then must comply with FERC's rate regulation under the FPA.

agency, authority, or instrumentality of any one or more of the foregoing, or any corporation which is wholly owned, directly or indirectly, by any one or more of the foregoing, or any officer, agent, or employee of any of the foregoing acting as such in the course of his official duty, unless such provision makes specific reference thereto.

11 PURPA creates a category called "nonregulated utility," defined by PURPA Section 3(9) PURPA, 16 U.S.C. $§ 2602(9)$, to be a utility not regulated by the state, such as a stateowned, municipally owned or cooperatively owned entity. The nonregulated utility has the PURPA obligation to purchase QF capacity and energy, and also has the obligation to establish the avoided cost prices. 16 U.S.C. $\S 824 a-3(f)(2)$. 
Under both the PURPA option and the state law option, this report describes alternative paths for avoiding or limiting the preemptive effect, clarifies necessary revisions to existing precedent as well as describes procedure innovations. For example:

Under the PURPA option and existing law, states can grant QF sellers incremental compensation above avoided cost, provided that this incremental compensation takes the form of cash grants, renewable energy credits, tax credits, and/or production-based incentive payments; or the state may set the rate above avoided cost as long as it issues a tax credit equal to the increment above avoided cost. This option is now available to states without any further action by FERC.

Under the FPA options, additional action is required of FERC. FERC could create "safe harbors," presumptions or other guidance that allows for state-established "offer price caps" for various technologies, projects and regions. If these offer price caps were adopted in state feed-in tariffs, they would allow sellers to comply with the FPA without having to obtain contract-by-contract approval. This option will require a FERC investigation and decision, through rulemaking, declaratory orders, or both.

Another option could exist under the FPA if existing FERC precedent is clarified and/or adjusted. FERC has exempted from the FPA those PURPA-certified "qualifying facilities" with capacity of $20 \mathrm{MW}$ and less. This exemption, this report argues, creates a path by which state feed-in tariffs can use prices chosen by the state without federal preemption. For this path to be clear, however, FERC precedent requires clarification and/or adjustment.

Part III describes the generic ways in which Congress could modify PURPA or FPA to reduce or eliminate their preemption reach over state-level feed-in tariffs.

Part IV addresses certain miscellaneous questions on price-setting methods. 


\section{State-Level Tariffs Based on a PURPA Mandate}

PURPA creates for retail utilities an obligation to buy capacity and energy from certain types of facilities. The statute makes state utility regulatory commissions responsible for administering that obligation with respect to retail utilities over which the state commission has jurisdiction. States can use the utility's PURPA obligation as a legal vehicle for creating feed-in tariffs. By relying on PURPA, they need not enact a separate state law.

This section (Part I) provides the background necessary to understand how to design state-level feed-in tariffs within PURPA's constraints. It explains that:

a. PURPA requires each utility to buy capacity and energy from FERC-certified "qualifying facilities." The sales price can be established either (a) by state commissions, in which case the price must equal the utility's "avoided cost" or (b) through utility-QF negotiations, in which case the price may exceed avoided cost.

b. PURPA administration is split between FERC (which grants QF status) and states (which determine avoided cost and administer the utility's purchase obligation).

c. In 2005, Congress authorized FERC to exempt utilities from PURPA QF purchase obligations if they are located where QFs have reasonable opportunities to sell into wholesale markets because of the availability of transmission access or RTO-organized markets. FERC has issued regulations governing the ability of utilities to request this PURPA exemption and has clarified that the utility is still obligated to purchase from QFs with a capacity of $20 \mathrm{MW}$ and less. FERC has granted this exemption to most requesting utilities.

d. $\quad$ FERC allows states to supplement a QF's avoided cost compensation (e.g., through cash grants, renewable energy credits, tax credits and/or productionbased incentive payments) as long as the supplement does not take the form of mandatory utility payments for power to the QF.

After providing this background, Part I summarizes NRRI guidance to states in how to design feed-in tariffs consistent with PURPA's constraints.

\section{A. PURPA Overview: A utility must buy capacity and energy from "qualifying facilities," priced at the utility's avoided cost}

Congress enacted Section 210 of PURPA to encourage the development of cogeneration and small power production, and to overcome utilities' traditional reluctance to purchase power from non-traditional entities. ${ }^{12}$ The statute requires each retail utility to purchase capacity and energy from "qualifying facilities" (QFs) at a price equal to the utility's avoided cost.

${ }^{12}$ FERC v. Mississippi, 456 U.S. 742, 750 (1982). 
In addition to granting QFs a right to sell to utilities, Section 210 and the associated FERC rules provide QFs another benefit: exemption from traditional rate regulation, by states under state law and by FERC under the Federal Power Act. ${ }^{13}$ A QF selling at a utility's avoided cost rate under PURPA thus has no obligation to demonstrate, to the states or to FERC, the reasonableness of its own costs. ${ }^{14}$

\section{B. PURPA Administration: FERC grants QF status; states determine avoided cost and administer the utility's purchase obligation}

In administering PURPA, the FERC and state commissions play distinct roles. FERC determines whether a generator meets the requirements for QF status. Each state commission must establish the avoided cost for the retail utilities subject to that state commission's jurisdiction. ${ }^{15}$ Here are the basics:

\section{FERC determines QF status}

Under PURPA, two types of facilities are eligible for QF status: "small power production" facilities and "cogeneration facilities." 16 16 U.S.C. 824a-3(a). A small power production facility is a generating facility with capacity of $80 \mathrm{MW}$ or less whose primary energy source is renewable energy (hydro, wind or solar), biomass, waste or geothermal resources. 16 U.S.C. 796(17)(A). Solar, wind, waste or geothermal facilities that were certified as QFs before 1995 are not subject to the $80 \mathrm{MW}$-or-less size requirement. 16 U.S.C. 796(17)(E).

To become a QF, a small power production facility must meet the size and fuel requirements set out in FERC's regulations. 18 C.F.R. 292.203(a).

Size requirements: Solar, wind, waste, or geothermal facilities certified as QFs before 1995 are not subject to any size limitations. For all other small power production facilities, the power production capacity, either on its own or in combination with the capacity of other small

1318 C.F.R. sec. 292.601(c). More detail on this exemption from FPA regulation appears in the discussion of the FPA, at Part II.E below.

${ }^{14}$ Wholesale sales of electricity outside of PURPA are subject to the Federal Power Act, which requires sellers to prove to FERC the reasonableness of their prices. Part II below discusses FPA regulation.

${ }^{15}$ When the retail utility is a "nonregulated utility," the obligation to establish the avoided cost prices lies with that entity. 16 U.S.C. $\S 824 \mathrm{a}-3(\mathrm{f})(2)$. As defined by PURPA Section 3(9) PURPA, 16 U.S.C. § 2602(9), a "nonregulated utility" is a utility not regulated by the state, such as a state-owned, municipally owned or cooperatively owned entity.

16 Because state feed-in tariffs will apply to renewables, the size and fuel requirements applied to cogeneration facilities as set forth in 18 C.F.R. 292.203(b), 292.205 and 292.207 are not discussed here. 
power production facilities (using the same energy resource, owned by the same person or its affiliates and located at the same site), may not exceed 80 MW. 18 C.F.R. 292.204(a).

Fuel requirements: A small power production facility's primary energy source must be biomass, waste, renewable resources (wind, solar, hydro), geothermal resources, or any combination thereof. Seventy-five percent or more of the total energy input must be from one of these sources, with the exception of biomass, which may comprise 50 percent of the total input (while the other $50 \%$ can be from non-QF qualified fuels, including fossil fuels). 18 C.F.R. 292.204(b). ${ }^{17}$

QFs can self-certify; a small power production facility meeting the size and fuel requirements, who files with FERC a notice of self-certification along with a Form 556, becomes entitled to PURPA's benefits without the need for FERC action. 18 C.F.R. 292.207(a). Alternatively, the owner of a small power production facility meeting the size and fuel requirements for QF status may file an application for FERC certification that the facility is a qualifying facility. 18 C.F.R. 292.207(b). FERC may revoke QF status for either self-certified or FERC-approved QFs if the facility fails to conform to any of the FERC's qualifying facility size and fuel criteria. 18 C.F.R. 292.207(d).

\section{State determines the utility's avoided cost}

"Avoided costs" is shorthand for the statutory phrase, "incremental cost of alternative energy," defined by statute to mean "the cost to the electric utility of the electric energy which, but for the purchase from such cogenerator or small power producer, such utility would generate or purchase from another source." ${ }^{18}$ Avoided cost has two components - capacity and energybecause PURPA obligates the utility to buy both products from the QF to the extent the utility can avoid capacity and energy costs by doing so.

FERC's regulations allow the QF to choose between an avoided cost price (a) that varies over the life of the contract (as the utility's avoided cost varies) or (b) that the state commission

17 A "primary energy source" means the fuel or fuels used for the generation of electric energy. 16 U.S.C. $\S 796(17)(B)$. Section 292.204(b) of FERC's regulations provide that:

(i) the primary energy source of the facility must be biomass, waste, renewable resources, geothermal resources, or any combination thereof, and 75 percent or more of the total energy input must be from these sources.

(ii) Any primary energy source, which on the basis of its energy content, is 50 percent or more biomass shall be considered biomass.

18

16 U.S.C. $824 a-3(d)$. 
estimates upfront at the time the QF creates a "legally enforceable obligation" with the utility. ${ }^{19}$ The QF creates this obligation by demonstrating its willingness and ability to sell. Estimates of future costs never track with reality, of course. FERC has determined, however, that a variation of actual avoided costs from the original estimates does not invalidate the originally determined avoided cost price. $^{20}$

PURPA's avoided cost cap applies only to prices mandated by the state. A QF can negotiate with a utility to sell some or all of its output to a utility at market-based rates, which can exceed avoided cost. ${ }^{21}$ A negotiated rate means the utility is volunteering to purchase,

19 FERC's rules, at 18 C.F.R. $\S 292.304(\mathrm{e})$, require states to take into account the following factors, to the extent practicable:

(1) Data regarding the utility's cost structure and plans to add capacity;

(2) "The availability of capacity or energy from a qualifying facility during daily and seasonal peak periods, including:"

(i) The ability of the utility to dispatch the qualifying facility;

(ii) The reliability of the QF;

(iii) Contract terms;

(iv) The extent to which scheduled outages of the qualifying facility can be coordinated with scheduled outages of the utility's facilities;

(v) The usefulness of energy and capacity supplied from a qualifying facility during system emergencies;

(vi) The individual and aggregate value of energy and capacity from QFs on the electric utility's system;

(vii) The smaller capacity increments and the shorter lead times available with additions of capacity from QFs.

(3) The relationship of the availability of energy or capacity from the QF to the ability of the electric utility to avoid costs, including the deferral of capacity additions and the reduction of fossil fuel use.

(4) "The costs or savings resulting from variations in line losses from those that would have existed in the absence of purchases from a qualifying facility, if the purchasing electric utility generated an equivalent amount of energy itself or purchased an equivalent amount of electric energy or capacity."

2018 C.F.R. $\S 292.304(b)(5)$ provides: "In the case in which rates for purchases are based upon estimates of avoided costs over the specific term of the contract or other legally enforceable obligation, the rates for such purchases do not violate this subpart if the rates for such purchases differ from avoided costs at the time of delivery." See also New York State Elec. \& Gas Corp., 71 FERC 61,027 (1995) (declining to find contract in violation of PURPA where rates based on avoided costs at time contract obligation was incurred exceed avoided cost).

21 See Order No. 697-A, Market Based Rates for Wholesale Sales of Electric Energy, Capacity and Ancillary Services by Public Utilities, 123 FERC para. 61,055, 2008 FERC LEXIS 788 at *548 (allowing QFs to make sales at market-based rates, and holding that certain QFs are 
whereas the premise of a feed-in tariff is that the state is mandating both the purchase and the price. Still, the opportunity for a negotiated PURPA price to exceed avoided cost suggests a path for a state that declines to adopt a mandatory feed-in tariff but that wants renewable sellers to receive compensation above avoided cost. The state could issue a rule committing utilities to negotiate above-avoided-cost prices consistent with commission guidelines that also guarantees rate recovery of the resulting costs.

FERC has imposed two important restrictions on the states' avoided cost price-setting practices: (a) if the state uses a competitive bidding process to establish avoided cost, the bidding cannot exclude non-QFs; and (b) avoided cost cannot include "externality adders." FERC announced these two restrictions in its 1995 Southern California Edison decision. ${ }^{22}$ In the case before FERC, the California Public Utilities Commission (California PUC) had established a three-step process by which utilities would carry out their PURPA obligations. First, utilities had to file a resource plan identifying potential resource additions. Based on these plans, the California PUC determined what new resources the utilities would add. Second, using cost data supplied by the utilities, the California PUC determined the utility's avoidable resource additions (i.e., the additions the utility would have made but for its purchases from QFs), and then determined "benchmark prices" for those avoidable additions. Third, the California PUC required utilities to conduct a $\mathrm{QF}$-only bidding process for each avoidable resource. As the policy was originally established, for each avoided resource, the utility had to enter into a standard contract with each QF whose bid came in below that resource's benchmark price. The winning bidders would receive the price bid by the second lowest bidder with respect to each avoided resource. Certain winning bidders would receive additional payments to reflect the assumed value to society of reduced air emissions.

In Southern California Edison, FERC held that the absence of non-QFs from the bidding process would produce rates exceeding avoided costs, in violation of PURPA. FERC also found that the "avoided cost" price could not include "environmental adders," i.e., a state's view of the cost to society from the environmental effects of electricity production. Southern California Edison, 71 FERC at 62,080. FERC subsequently has made clear that when externalities become "monetized" (i.e., internalized by the utility as actual costs) they can be properly included in the avoided cost calculation. Monetization occurs through policy mechanisms such as emission tax or cap and trade regimes, which raise the utility's power purchase costs. ${ }^{23}$

exempt from market-based rate approval under criteria of 18 C.F.R. 292.601(c)(1). The concept of market-based rates is discussed at Part II.D.2 below.

22 Southern California Edison decision. 70 FERC para. 61,215 (1995), aff'd on rehearing, 71 FERC para. 61,269 (1995).

23 FERC explained (71 FERC at 62,080):

"Thus, in setting avoided cost rates, a state may only account for costs which actually would be incurred by utilities. A state may, through state action, influence what costs are incurred by the utility. Thus, accounting for 
Conclusion: If a state relies on PURPA as the legal basis for the feed-in tariff, and if the state uses competitive bidding to determine avoided cost price, the state must allow QFs and non-QFs to participate in the bidding. As put forward in the Federal Power Act section (Part II below), if FERC clarifies and/or adjusts its precedent the state can avoid this restriction by relying on a state law mandate rather than PURPA as the basis for requiring utilities to purchase renewable power.

\section{PURPA Shrinkage: FERC has exempted some utilities from PURPA's purchase obligation}

The Energy Policy Act of 2005 (EPAct) amended PURPA by authorizing FERC to exempt an electric utility from its PURPA obligation to buy from a QF if the QF has "nondiscriminatory access" to at least one of three things:

"(A) (i) independently administered, auction-based day ahead and real time wholesale markets for the sale of electric energy; and (ii) wholesale markets for long-term sales of capacity and electric energy; or"

"(B) (i) transmission and interconnection services that are provided by a Commission-approved regional transmission entity and administered pursuant to an open access transmission tariff that affords nondiscriminatory treatment to all customers; and (ii) competitive wholesale markets that provide a meaningful opportunity to sell capacity, including long-term and short-term sales, and electric energy, including long-term, short-term and real-time sales, to buyers other than the utility to which the qualifying facility is interconnected. In determining whether a meaningful opportunity to sell exists, the Commission shall consider, among other factors, evidence of transactions within the relevant market; or"

“(C) wholesale markets for the sale of capacity and electric energy that are, at a

environmental costs may be part of a state's approach to encouraging renewable generation. For example, a state may impose a tax or other charge on all generation produced by a particular fuel, and thus increase the costs that would be incurred by utilities in building and operating plants that use that fuel. Conversely, a state may also subsidize certain types of generation, for instance wind, or other renewables, through, e.g., tax credits."

"A state, however, may not set avoided cost rates or otherwise adjust the bids of potential suppliers by imposing environmental adders or subtractors that are not based on real costs that would be incurred by utilities. Such practices would result in rates which exceed the incremental cost to the electric utility and are prohibited." 
minimum, of comparable competitive quality as markets described in subparagraphs (A) and (B)."24

A utility seeking to terminate its purchase obligation may file an application with FERC on a service territory-wide basis. 18 C.F.R. $\S 292.310$. For purposes of evaluating these utility applications, FERC has created three "rebuttable presumptions." 25 There is a rebuttable presumption that:

1. In markets operated by the Midwest Independent Transmission System Operator (MISO), PJM Interconnection, ISO-New England, the New York Independent System Operator (NYISO) and the Electric Reliability Council of Texas (ERCOT), QFs with a net capacity of greater than 20 megawatts have nondiscriminatory access and that utilities in these markets should be relieved of their purchase obligations. 18 C.F.R. $\S 309(e)$, (f)).

2. In all markets, QFs with a net capacity of greater than $20 \mathrm{MW}$ have nondiscriminatory access to markets if they are eligible for service under a FERCapproved open access transmission tariff or a "reciprocity" tariff filed by nonjurisdictional transmission owners. 18 C.F.R. $\S 309(\mathrm{c})$.

3. Small QFs (with net capacity of $20 \mathrm{MW}$ or less) do not have non-discriminatory access to any wholesale electric markets. 18 C.F.R. $\S 309(d)(1){ }^{26}$

24 16 U.S.C 824a-3(m)(1)(A)-(C); see also the FERC regulations implementing EPAct changes to PURPA, 18 C.F.R. 292.309 (2009). Because of the importance of this regulation to states contemplating feed-in tariffs, the full regulation appears in Appendix B.

25 A "rebuttable presumption" places the burden of producing contrary evidence on the person opposing the presumption. This means that unless an opponent offers contrary evidence (i.e., "rebuts" the presumption), the presumption is deemed true and the entity receives the benefits of the presumption.

${ }^{26}$ A QF (or an intervenor) may rebut the presumptions described in paragraphs 1 and 2 above by showing either that it has certain operational characteristics that effectively prevent it from participating in the market or that it lacks access because of transmission constraints. 18 C.F.R. 292.309(a)(3)(c)(establishing criteria for rebutting presumption that QF has nondiscriminatory access where eligible for open access tariff); 18 C.F.R. 292.309(e)(1)-(2) and (f)(1)-(2)(establishing criteria for rebutting presumption that QF has non-discriminatory access in MISO, NYISO, PJM, ISO-New England and ERCOT markets).

When a utility makes an application to terminate its mandatory purchase obligation, FERC must notice the application and allow public comment, during which time a state commission or any other interested party may object to a utility's termination request. 18 C.F.R. 292.310(a) (requiring notice of application to terminate mandatory purchase obligation). 
A state intending to rely on PURPA for its feed-in tariff first must determine if its utilities have obtained a FERC exemption. ${ }^{27}$ If PURPA still applies and there is not a FERC exemption, the state can proceed. However, if the PURPA mandate does not apply to the QF's host utility, ${ }^{28}$ and if there is no other utility the QF can "tag" with a purchase obligation (as explained in the next paragraph), then PURPA cannot be used. Instead, (a) the state must create its own legal mandate to purchase from renewables, and (b) Sections 205 and 206 of the Federal Power Act (i.e., the provisions requiring that rates be just and reasonable) will apply to the renewable seller (unless FERC has exempted the seller because its capacity is $20 \mathrm{MW}$ or less). This non-PURPA route is explained in Part II below.

Where a QF's host utility has obtained this FERC exemption, it is not clear to what extent the QF can require other utilities to buy its power. FERC's PURPA regulations (unchanged by the EPAct 2005 amendment) allow a QF to have the host utility transmit the QF's output to other utilities, which then would have the PURPA purchase obligation. Specifically, 18 C.F.R. sec. 292.303(d) states that

"[A]n electric utility which would otherwise be obligated to purchase energy or capacity from such qualifying facility may transmit the energy or capacity to any

27 Here is a sampling of FERC decisions: "Order granting application to terminate purchase obligation and denying late intervention" in Duke Energy Shared Services, Inc. et al., 119 FERC \ 61,146 (May 17, 2007); "Order Granting in Part and Denying in Part Application" in Xcel Energy Services, Inc, Southwestern Public Service Company, Oklahoma Gas and Electric Company et al., 122 FERC $\mid 61,048$ (January 22, 2008); “Order granting application to terminate purchase obligation” in American Electric Power Services Corp et al., 120 FERC $\uparrow$ 61,052 (July 18, 2007) (filed on behalf of certain operating companies, which in sum are referred to as AEP East. AEP East is made up of: Appalachian Power Company, Columbus Southern Power Company, Indiana Michigan Power Company, Kentucky Power Company, Kingsport Power Company, Ohio Power Company, and Wheeling Power Company); "Order granting application to terminate purchase obligation in Virginia Electric and Power Company, 124 FERC $\uparrow$ 61,045 (July 17, 2008); “Letter order accepting PPL Electric Utilities Corp's 7/22/09 filing of an Application for Authorization to Terminate the Mandatory Purchase Obligation from Qualifying Facilities with Net Capacity Over Twenty Megawatts on a Service-Territory-wide Basis,” Docket No. QM09-6 (October 14, 2009). This list will likely expand as more utilities apply for the exemption.

Note the citation of Southwestern Public Service Company above "denying in part" a utility's application to terminate the purchase obligation. In it, FERC denied Xcel Energy's request to terminate its mandatory purchase obligation where a wind-qualified facility rebutted the presumption of a competitive market by offering specific evidence of transmission constraints that precluded it from accessing third-party purchasers. 122 FERC para. 61,048 at 61326.

28 "Host utility" means the utility in whose service territory the QF project is located. 
other electric utility. Any electric utility to which such energy or capacity is transmitted shall purchase such energy or capacity under this subpart as if the qualifying facility were supplying energy or capacity directly to such electric utility."

There are several uncertainties about how this provision will operate. First, the host utility's duty to transmit to another utility, making this second utility obligated to purchase the QF's power, exists only if the host utility is "otherwise obligated to purchase." If FERC, pursuant to the 2005 statutory amendment, has terminated the host utility's purchase obligation, the host utility might argue that it is no longer "otherwise obligated." That reasoning creates doubt as to whether the QF can rely on this regulation to "tag" the second utility. (FERC could (a) accept the utility's argument, (b) condition the exemption from the purchase obligation on the utility's continuing to have the transmission obligation, or (c) interpret the "otherwise obligated" phrase to mean that the utility was obligated but for the 2005 amendment and therefore is still obligated). Second, since every utility has an obligation to transmit power under FERC Order 888 , the relevance of this provision is unclear. Note also that in the context of a regional transmission organization (RTO), FERC's Order 2000 requires the RTO to provide transmission throughout its multi-utility territory at a single rate. That obligation makes it possible that the QF located in the RTO's territory could require a purchase from any utility that has not received from FERC an exemption from the PURPA purchase obligation. FERC clarification of these points would be useful.

The exemption from PURPA is not guaranteed by statute; it depends on factual findings made by FERC. A state can protest a utility's exemption request, challenge a FERC decision in court, and/or petition FERC to eliminate an exemption already granted. Further, FERC has an obligation to modify or remove a previously granted exemption if the market facts vary from those on which FERC originally relied. See 18 C.F.R. $\$ 292.311$ (describing procedure for reinstating obligation to purchase).

One might argue that Congress, in authorizing FERC to exempt utilities from their PURPA purchase obligations, intended the broad result of preempting any state law that mandated a utility purchase. The 2005 statute does not support this argument. The U.S. Supreme Court has stated repeatedly that it will find preemption only if Congress had made its intent clear. ${ }^{29}$ Here, Congress confined its clarity to relieving utilities of their PURPA obligations.

\section{Compensation for PURPA Sellers: States can-with care-grant renewable sellers compensation exceeding the utility's avoided cost}

Although this report discusses multiple uncertainties concerning a state's ability to promulgate a feed-in tariff, the state's path is clear with one category of transactions: $\boldsymbol{A}$ tariff

${ }^{29}$ Pacific Gas \& Elec. Co. v. State Energy Resources Conservation \& Development Comm'n, 461 U.S. 190 (1983); Rice v. Santa Fe Elevator Corp., 331 U.S. 218 (1947). 
established under PURPA, where the state supplements the avoided cost payment with compensation in a form FERC has already approved, is free from federal preemption.

A utility's avoided cost will likely fall below the compensation necessary to attract renewable producers of the type, quality, and quantity desired by most states. The reason is straightforward: Absent a renewables mandate, the utility would procure non-renewable power (sometimes called "generic power"), whose price is usually lower than renewable power.

There are solutions, however. States basing their feed-in tariffs on the PURPA mandate (which imposes the avoided cost price cap unless the price is negotiated) can lawfully grant renewable energy generators compensation exceeding avoided cost. The key to accomplishing this objective is that this compensation not be part of the price that the utility pays for purchasing power under the PURPA mandate. FERC decisions make at least three alternatives available. ${ }^{30}$

\section{Renewable energy credits awarded to the renewable seller ${ }^{31}$}

A renewable energy credit or certificate (REC), also known as a "green tag," is a tradable commodity representing proof that a unit of electricity (e.g., $1 \mathrm{MWh}$ ) was generated from an eligible renewable energy resource. Some states that require utilities to purchase renewable energy have created REC-ownership tracking systems to document a utility's compliance with that purchase mandate. Businesses and individuals might also buy RECs to meet company or personal environmental goals. A REC entitles its owner to assert that it has produced or purchased renewable energy in the amount, and from the resource, stated by the certificate. Legal rights associated with the REC include the right to sell it within the rules of the tracking system and the ability to demonstrate compliance with a renewable purchase mandate.

Where a REC has financial value, it offers states one way to compensate renewable generators above utility avoided cost. To do so, the state would take two steps. First, acting under PURPA, the state would establish the tariff's mandatory offer price for power at the utility's avoided cost. Then, the state could award RECs to each renewable project owner for all MWh produced. The renewable owner can sell the REC to others, either with or separately from the energy produced.

30 These same options will apply in the Federal Power Act, as explained in Part II below. If the state is basing the utility's obligation to purchase on state law rather than PURPA, the seller must receive FPA approval for the sale. If the compensation deemed by the state as necessary to attract the seller exceeds FERC's view of just and reasonable prices, it is believedalthough there is no FERC precedent on this point, one way or the other-that the state is free to grant that extra compensation through these same non-rate means.

31 Scott Hempling, the main author of this report, provided legal analysis for this section. Information about renewable energy certificates and their markets was primarily written by Karlynn Cory and Kevin Porter, with input from Robert C. Grace of Sustainable Energy Advantage. 
This extra compensation does not violate PURPA's avoided cost standard. In American Ref-Fuel Co. ${ }^{32}$ FERC found that RECs are not part of the PURPA-mandated compensation from utility to QF; the avoided cost rate compensates the QF for capacity and energy, but not for renewable attributes. From this basis, FERC reasoned:

"If avoided cost rates are not intended to compensate a QF for more than capacity and energy, it follows that other attributes associated with the facilities [such as renewable attributes] are separate from, and may be sold separately from the capacity and energy...."

"... RECs are created by the States. They exist outside the confines of PURPA. PURPA thus does not address the ownership of REC.... States, in creating RECs have the power to determine who owns the REC in the initial instance and how they may be sold or traded; it is not an issue controlled by PURPA."

American Ref-Fuel Co., 105 FERC para. 61,004 (2003) at para. 23.

FERC thus found that states have unrestricted authority (that is, unrestricted by federal law) to create RECs, to establish their value by determining procedures for their purchases and sales, and to assign these value-laden RECs to renewable generators (or others). None of these options represents "an issue controlled by PURPA." In this respect, RECs resemble the tax credits and cash payments that FERC views as distinct from avoided cost payments and outside FERC's legal domain. (See Part I.D.2 immediately below). Because the REC is not part of the price of the PURPA-mandated purchase of power, the REC compensation to QFs would not violate PURPA's avoided cost cap, even if the utility's REC purchase is "bundled" with its avoided cost PURPA power purchase. The key is that the utility's obligation to buy RECs (which is outside PURPA's domain) be stated separately from the utility's obligation to buy power (which is within PURPA's domain, and thus must be capped at avoided cost).

If REC prices are determined by market forces, it is not certain that the sum of the PURPA avoided cost compensation and market-based REC compensation will produce revenue sufficient in quantity and predictability to attract the desired types and quantities of renewable sellers. Further, different technologies will require different levels of compensation, so fungible RECs whose prices are set by market forces would pose a challenge to implementing tariffs whose prices differ by technology.

One possible solution — briefly mentioned here and not fully explored — is for states to create a class of REC in conjunction with state FIT policies. The state may be able to order the utility to buy such RECs at a price established as the difference between the target compensation for the seller and the utility's avoided cost under PURPA. This state-set REC price may vary

32105 FERC \ 61,004, at P23 (2003), request for reh'g denied, 107 FERC 9 61,006 (2004), appeal dismissed, Xcel Energy Servs., Inc. v. FERC, 407 F.3d 1242 (D.C. Cir. 2005). 
with the technology (and perhaps project size) because different projects will have different costs. In considering this option, several issues merit consideration:

- In some contexts, RECs are fungible: RECs from one renewable source will be valued the same as from another renewable source. Yet in others, REC prices from generators within in the same state or region may differ based on their type. For example, many states have established distinct renewable portfolio standard 'tiers' or classes with differing eligibility and for which REC price caps and prevailing prices may differ. ${ }^{33}$

- REC prices have been most typically dictated by market dynamics or competitive procurements. They may vary within and across regions, and over time. Some RECs are transacted long-term, others short-term; sometimes bundled with energy and/or capacity, other times unbundled.

- For states with an RPS that includes a fixed alternative compliance payment (ACP), interactions between the state-set REC prices and the ACP must be explored.

It is beyond the scope of this report to fully assess whether the sum of the PURPA avoided cost compensation plus REC compensation will be sufficient for renewable energy development. Future studies, guided by the legal parameters set forth in the present report, should focus on ways for states to align REC compensation with sellers' needs.

\section{Tax credits awarded to the utility purchaser}

FERC allows a state to set a PURPA purchase price exceeding avoided cost, if the state then grants the purchasing utility a tax credit equal to the excess. CGE Fulton ${ }^{34}$ involved an Illinois state law implementing PURPA. The law required utilities to purchase power from a PURPA-qualified municipal waste burning facilities at rates equal to the retail rate charged by the utility to the municipality owning the facility. That rate exceeded the utility's avoided cost. The statute also provided a monthly tax credit to the utility for amounts paid above avoided cost.

FERC rejected the utility's challenge, because the tax credit meant that "the effective rate is intended to be equal to - and not above - the electric utility's avoided cost." FERC explained:

"[W]e note that there is no question that a state could provide tax credits (and/or direct cash subsidies for that matter) to certain types of sellers of electric energy, including QFs or certain types of QFs, without violating section 210 of

PURPA....By providing a tax credit to the purchasing electric utility, the Illinois

Legislature effectively capped the rate paid by the electric utility at its avoided

33 In some states, solar technologies or distributed projects are separated into their own tier in the RPS, and the project costs and penalty prices are higher than they are for other RECs.

3470 FERC para. 61,290, reconsideration denied, 71 FERC para. 61,232 (1995). 
cost, while providing additional taxpayer-funded benefits to a category of QFs. Under Illinois' scheme, amounts above avoided cost are paid by taxpayers, not by the purchasing utility or its ratepayers."

FERC elaborated in its Order on Rehearing:

"[H]ere the purchasing utility is not required to pay in excess of avoided cost. That a state may choose to grant loans, subsidies or tax credits to particular facilities on environmental or other policy grounds is not inconsistent with PURPA."

A state's ability to supplement the avoided cost price is not confined to tax credits awarded to the purchasing utility. Loans, subsidies - and, of course, REC assignments - are all lawful means of supplementing the seller's compensation.

The CGE Fulton approach is necessary only if the state is relying on PURPA as the legal basis for compelling a utility to buy renewable power. If state law establishes a distinct, non-PURPA mandate for the utility to offer to buy from the renewable entity, and if FERC clarifies and/or adjusts its precedent, the state may set whatever offer price it wishes, without PURPA preemption. In that context, however, the FPA applies and requires the seller to show that its sales price is "just and reasonable." The FPA, unlike PURPA, preempts a state from commanding a purchase at a specified price. As explained in Part II.B below, under the FPA the state can only order its utility to offer to buy; any resulting contract must go to FERC for approval.

Tax credit caution: To comply with PURPA's avoided cost cap, the Illinois statute in $C G E$ Fulton provided a monthly tax credit to the utility for purchase payments exceeding the utility's avoided cost. ${ }^{35}$ What if the state tax liability is lower than the increment of the state-set price above the utility's avoided cost? In that situation, there would be a PURPA violation, because the tax credit would not fully reimburse the utility for its payments above avoided cost. A utility's low tax liability thus restricts the viability of the CGE Fulton solution. If the credit necessary to make the net utility payment equal to avoided cost exceeds the utility's tax liability, one solution is to make the tax credit refundable; meaning, the state writes a check to the utility for the excess amount. This adjustment would require state legislation.

35 Two other nuances, according to FERC: (1) "[T]he electric utility is excused from its obligation to purchase electricity at the above rate if the tax credits would exceed, on a monthly basis, the utility's estimated taxes." and (2) "[O]nce the facility has paid in full its capital costs or indebtedness incurred in developing and implementing the project, the facility is required to reimburse the Illinois state treasury for the tax credits."

The Illinois statute relieves the utility of its obligation to purchase at that statutory rates (i.e., the average amount per kilowatt-hour paid by the unit local government in which the electricity generating facilities are located) when the tax credits would exceed the utility's tax liability for a given month. 220 ILCS 5/8-403.1(d). 


\section{Payments to the renewable seller from other sources}

In CGE Fulton, FERC stated that "a state may choose to grant loans, subsidies or tax credits to particular facilities on environmental or other policy grounds" without violating PURPA. This general statement opens many doors for a state seeking to grant the seller compensation exceeding utility avoided cost. Tax credits to the seller, cash payments emanating from "system benefit charge" revenues, cash payments flowing from general tax revenues (upfront or production based), funding from any source - all these options are available to the state when relying on PURPA as the mandate for utility purchases. ${ }^{36}$

Part II below will note that the same options will apply in the Federal Power Act scenario. If the state is acting outside PURPA (and thus under state law) so that the seller must receive FPA approval for the sale, and if the compensation deemed by the state as necessary to attract the seller exceeds FERC's view of just and reasonable prices, the state is free to award that extra compensation through these non-rate means. However, this application of non-rate compensation has not been specifically applied to FPA by FERC.

\section{The problem of avoided cost variability}

A utility's avoided cost varies with the utility's needs and with market circumstances. If the utility brings on a new major capacity addition, its avoided capacity cost will drop. If the cost of fuel drops, so will the utility's avoided energy cost. Conversely, if a planned project is cancelled or the cost of fuel increases, the utility's avoided energy cost will increase. Today, states address these realities by periodically changing the utility's official avoided cost rate. As noted in Part I.B.2 above, FERC's regulations address this concern by allowing a QF to lock in an avoided cost estimate upfront, determined by the state at the time of the QF's "legally enforceable obligation," thereby setting a fixed price for the life of the contract.

If a QF chooses the option of variable avoided cost payments, this variability poses a challenge to the feed-in tariff designer who wishes to establish a reliable revenue stream over the renewable project's life. They can solve the problem with a two-part approach made possible by the FERC's decisions in American Ref-Fuel and CGE Fulton. By combining (a) a generic power price, equal to avoided cost, paid by the utility, with (b) incremental compensation to the QF, separately funded (such as a state-required utility purchase of the REC, or system benefit charge revenue), where the size of the compensation varies inversely to periodic changes in the utility's avoided cost, the state eliminates the awkwardness. The sum of the avoided cost compensation and the incremental compensation - each of which will vary in opposite directions - will be a stable stream of income to the renewable seller.

36 Although "system benefit charge" revenues come from ratepayers, their use here would not violate PURPA's avoided cost cap because they are not part of the mandatory rate paid by the utility to the QF. 


\section{Can the state set different PURPA prices for different technologies?}

Under PURPA, the power sales price, if mandated by the state, must equal the utility's avoided cost. Avoided cost is the cost the utility would incur had it supplied its needs by means other than buying from the QF. As a general principle, that utility's avoided cost does not vary with differences in QF technology. ${ }^{37}$ If a state wishes to compensate different technologies at different amounts, it can do so by varying the state grants, production-based incentives, or tax credits that supplement the utility's avoided cost payment.

\section{E. Application of PURPA concepts to state feed-in tariffs: Summary of the three steps}

A state seeking to use the PURPA mandate as the context for its feed-in tariffs, must take the following steps:

1. Determine whether FERC has exempted its utilities from a PURPA must-buy obligation. See Part I.C above.

2. Align the eligibility criteria for the feed-in tariff with FERC's rules for certifying QFs. See Part I.B.1 above.

3. Establish a process for granting the seller compensation in excess of avoided cost, in a manner that complies with PURPA. See Part I.D above. The options for setting seller compensation are:

a. The state can declare that the seller's production includes two distinct goods: generic power and a REC. The price set under the feed-in tariff would reflect the utility's avoided cost of procuring generic power. The state then would award the seller the value of the REC, calculated by the state to equal the compensation gap. The award of REC value to the seller could occur through several means: (a) the state awards the REC directly to the seller (who then can sell it on the market); (b) the state could pay the seller for the REC, using taxpayer funds or system benefit charge funds; or (c) the state could command the utility to buy the REC from the seller (then allow the utility to recover the cost from ratepayers).

b. The state can set the purchase prices at a level exceeding avoided cost but give the utility a tax credit for the difference.

37 Note, however, that FERC rules state that a utility's avoided cost rates "may differentiate among qualifying facilities using various technologies on the basis of the supply characteristics of the different technologies.” 18 C.F.R. $§ 292.304(c)(3)(i i)$. 
c. The state can award the seller a grant or loan (either upfront or production-based), paid for with taxpayer funds of system benefits charge funds. 


\section{State-Level Tariffs Based on a State Law Mandate}

In this category of transactions, the utility's obligation to file a feed-in tariff arises from a state statute rather than PURPA. The state legislature enacts a statute requiring its utilities (or authorizing the state commission to require the utilities) to buy capacity and energy, and possibly RECs, from defined categories of sellers. The statute makes no reference to PURPA. For states whose utilities have received from FERC a PURPA exemption (see Part I.C above), a state law mandate is their only option.

Because this category of transactions involves wholesale sales outside of PURPA, it implicates the Federal Power Act. The FPA vests in FERC exclusive jurisdiction over all wholesale sales in interstate commerce (unless those sales are subject to PURPA). FERC has a statutory obligation to ensure the prices for these transactions are "just and reasonable" and not "unduly discriminatory." To prove justness and reasonableness, the seller has two options: seek FERC approval of a specific "cost-based" price on a contract-by-contract basis (i.e., a price designed to cover the seller's prudent costs plus a reasonable return on equity); or seek FERC's approval of "market-based rate authority" (i.e., the right to charge any price - which FERC will grant only if the seller proves it has no market power). FERC has no statutory ability to supplement "just and reasonable" prices to ensure attractiveness to renewable sellers. As with PURPA (see Part I.D above) it is presumed that states can supplement the FERC-approved prices, such as with RECs and cash grants and above-market prices accompanied by tax credits for the purchasing utilities (although FERC has not clarified this specifically).

Part II explains how the Federal Power Act affects states seeking to design feed-in tariffs, and sellers seeking to sell under those tariffs. FERC clarification and/or adjustments to its precedent will be required. Although the FPA grants FERC exclusive jurisdiction over wholesale sales, this report argues that a state can establish feed-in tariffs, free of FPA preemption, if those tariffs play a limited role: establishing a utility's offer to buy power at a state-specified rate, subject to ultimate FERC approval. A seller choosing to accept that offer then must (a) enter into a contract with the purchasing utility and (b) obtain FERC authorization of that contract, before a sale can lawfully occur. This report explains that FERC modification of its precedent is necessary for this option to be free of legal risk.

After explaining these FPA fundamentals, Part II describes the sellers' obligation to obtain FERC's permission to sell. They must choose either (a) contract-by-contract "cost-based" review or (b) advance, blanket permission under FERC's "market-based rate" program. Because FERC consideration under the FPA of state-mandated offer prices is a new concept, both options involve uncertainties.

In addition, FERC has exempted PURPA QFs under $20 \mathrm{MW}$ from its FPA review. This exemption creates a means for states to enact more traditional feed-in tariffs for that category of sellers; but this option also is uncertain without FERC clarification.

Part II concludes with recommendations on how FERC could modify its procedures, if it chooses to facilitate state-level feed-in tariffs. 


\section{A. Federal Power Act Overview: FERC has exclusive jurisdiction to set wholesale rates}

Since 1935, the Federal Power Act has placed in the Federal Energy Regulatory Commission (previously the Federal Power Commission) the exclusive authority to regulate "the sale of electric energy at wholesale in interstate commerce." ${ }^{38}$ It is unlawful to make a sale at wholesale without proving to FERC that the price is "just and reasonable" and not "unduly discriminatory."

FERC's authority includes the exclusive authority to set the rates for these wholesale sales. ${ }^{39}$ FPA Section 205 thus directs FERC to review and ensure the justness and reasonableness of:

38 Section 201 of the FPA provides:

(a) It is hereby declared that the business of transmitting and selling electric energy for ultimate distribution for the public is affected with a public interest, and that Federal regulation of that part of such business which consists of the transmission of electric energy in interstate commerce and the sale of such energy at wholesale in interstate commerce is necessary in the public interest, such Federal regulation, however, to extend only to those matters which are not subject to regulation by the states.

(b)(1) The provisions of this Part shall apply to the transmission of electric energy in interstate commerce and to the sale of electric energy at wholesale in interstate commerce.

In Federal Power Act law, the term "interstate commerce" has a technical meaning. Under precedent unchanged (and undisputed) since the early 1970s, all wholesale transactions within the interconnected grid, even if the contractual origin and destination are within a single state, are within "interstate commerce" and therefore subject to FERC's jurisdiction. See FPC $v$. Florida Power \& Light Co., 404 U.S. 453, 454-55 (1972) (recognizing that electrons from intrastate sale in Florida move in interstate commerce because of commingling of intrastate and interstate power at point of interconnection with out-of-state utility). Thus, a sale by a wind generating plant in Nevada to a utility located in Nevada is in "interstate commerce."

The Federal Power Act does not apply to Hawaii, Alaska, and most of Texas because these areas are not connected to the interstate electric grid. (That is why the Hawaii Public Utilities Commission, which one of the authors advised, could promulgate a feed-in tariff order without considering FPA issues.) PURPA, in contrast, applies to all states, except to the extent where FERC, acting under authority granted by Congress in 2005, has exempted utilities from their PURPA purchase obligations.

39 Miss. Power \& Light Co. v. Miss. ex rel. Moore, 487 U.S. 354, 371, 108 S. Ct. 2428, 2439 (1988) (describing FERC's "exclusive authority to determine the reasonableness of 
"all rates and charges made, demanded or received by a public utility [either through a rate schedule or contract] for or in connection with the sale of electric energy subject to the jurisdiction of the Commission." ${ }^{40}$

Where rates for wholesale transactions are unjust, unreasonable, or unduly discriminatory, Section 206 of the FPA requires FERC to determine and re-set wholesale rates itself. ${ }^{41}$

\section{B. To avoid FPA preemption, states must fashion their feed-in tariffs as offers to purchase, but even then legal uncertainty exists}

Although FERC has exclusive jurisdiction over wholesale sales, states have jurisdiction over wholesale purchases by retail utilities. This federal-state jurisdictional relationship allows states to command their retail utilities to make offers to purchase at a specified rate, subject to FERC's ultimate authority to review and approve the terms of any sale that results when a seller accepts the utility's offer. The ensuing discussion will describe FERC pronouncements that require clarification and/or adjustment, if states are to be able to design tariffs that suit their needs while avoiding FPA preemption.

\section{FPA Background: FERC's preemptive authority over wholesale sales}

The Federal Power Act forces market entities to conduct transactions within contracts that are under FERC jurisdiction. In other words, it is unlawful to sell at wholesale without a FERC-authorized contract. ${ }^{42}$ Only FERC can establish the rates, terms and conditions for a wholesale sale. There is no lawful transaction until FERC approves it.

This legal fact means that a state-level tariff that relies on state law (and not PURPA), by itself, cannot give life to a transaction. This conclusion highlights the fundamental difference between U.S. law and the typical European-style feed-in tariff. The latter tariff contains the full

wholesale rates"); FPC v. S. Cal. Edison Co., 376 U.S. 205, 215216, 84S. Ct. 644, 651 (1964) ("Congress meant to draw a bright line easily ascertained, between state and federal jurisdiction . ... This was done in the Power Act by making FPC jurisdiction plenary and extending it to all wholesale sales in interstate commerce except those which Congress has made explicitly subject to regulation by the States.").

${ }^{40} 16$ U.S.C. sec. $824 d(a)$.

${ }^{41} 16$ U.S.C. sec. $824 \mathrm{e}$.

${ }^{42}$ Part II.D below explains that sellers can obtain FERC authorization in two alternative ways: on a contract-by-contract basis, whereby the seller submits each contract for approval (known as cost-based regulation); or on a pre-approval, blanket basis, whereby the seller receives advance approval to enter into contracts at will without the need for further review (known as market-based regulation). 
set of rights and responsibilities: any eligible seller has a right to sell, merely by connecting with the purchasing utility and complying with the tariff terms. Under the FPA, the state-level tariff can be only the first step in a process that culminates in FERC approval of a contract.

Further, a state-level tariff cannot lawfully command the utility to purchase at the state-set price. What if FERC, reviewing a state-mandated purchase, were to find the state-set price unjust and unreasonable, and require a different price? The utility then would be in an unworkable position: it could not simultaneously comply with the state's command to buy at one price and FERC's command that the contract have a different price. To avoid this position of impossibility, Congress has made FERC's price-setting authority preemptive of states. ${ }^{43}$

\section{State authority to require offers to purchase is not preempted if FERC clarifies or adjusts its existing precedent}

Does FERC's exclusive authority over wholesale sales mean that U.S. law bars state-level feed-in tariffs outside of PURPA? This subsection argues that the answer is "no," provided that the state designs the tariff to be the utility's offer to buy at a state-specified price. This analysis is not free from doubt; the subsequent subsection describes FERC precedent that will require clarification or modification to remove legal uncertainty.

In this FPA context, it is necessary first to distinguish a "tariff" from a "contract," or more specifically, a state-jurisdictional tariff from a FERC-jurisdictional contract. In the context of utility purchases, a tariff creates a general legal obligation to buy the products described in the tariff, under the terms and conditions set forth in the tariff, from any seller made eligible by the tariff. Under this tariff description, the tariff itself does not establish a contract, i.e., a mutual obligation to buy and sell. Accompanying the tariff, therefore, is a standard contract, sometimes called a service agreement. That contract would state the names of the buyer and seller, the seller's characteristics, and other information necessary under state law to establish a contract, and would reference the tariff as the source of the rates, terms and conditions applicable to the contract. In the context of FPA-jurisdictional agreements, the contract would become effective only upon FERC's authorization.

If the state-mandated tariff is merely an offer to buy, it does not, by itself, purport to establish a wholesale price or complete a wholesale contract. It is an offer only. The seller, on accepting that offer, would enter into a contract with the retail utility. That contract is a FERC-jurisdictional contract, meaning it has legal force only if FERC allows it. The state-level feed-in tariff starts the contractual process, but there is no transaction until FERC approves the contract.

Under this approach, the state tariff remains several steps removed from FERC's exclusive jurisdiction over the wholesale sale. The seller and FERC, not the state, determine whether a transaction will occur, because there is no transaction unless the seller enters a contract with the utility and obtains FERC authorization of that contract. While the state sets the

43 See Appendix A for an explanation of "conflict preemption." 
offer price, there is no contract price until the seller accepts the buyer's offer and obtains FERC's approval to sell at that price. ${ }^{44}$

Because the state's feed-in tariff is merely an offer to buy, FERC jurisdiction to determine the lawfulness of the consummated transaction is unaffected. FERC will review the contract for consistency with the FPA's requirement that wholesale contracts be just and reasonable and not unduly discriminatory. FERC has full discretion to disapprove the contract or condition its approval on modifications, including the rates. The state has taken no action to interfere with this discretion. The state has only directed its retail utilities to have on file, at the state commission, a tariff that offers to buy power at a specified rate. That tariff is merely a means by which the state guides the purchasing decisions of its retail utilities. ${ }^{45}$ And, if FERC conditions its approval on modifications to the contract, the parties need not accept those modifications; the standard terms set forth in the state-mandated offer can leave the utility free to withdraw its offer.

By characterizing (and designing) the feed-in tariff as state regulation of the utility's purchasing practices, the state action would fall within a legal area long protected from preemption by the FERC and the courts. FERC has stated: "The Commission has consistently recognized that wholesale ratemaking does not, as a general matter, determine whether a purchaser has prudently chosen from among available supply options." 46

FERC has elaborated as follows:

${ }^{44}$ Cf. Commonwealth of Massachusetts v. United States, 729 F.2d 886 (1st Cir. 1984) (finding that FPA preempted state commission from directing a retail-utility-as-wholesale-seller to make a filing a FERC; Section 205 of FPA envisions voluntary rate filings at FERC by wholesale sellers).

45 It is the prospect of FERC review and modification that concerns advocates of feed-in tariffs, where the purpose is to guarantee sellers a known revenue stream, which drives down financing costs and transaction costs and, through that certainty, encourages development of competitive markets for manufacture and installation.

46 Cent. Vt. Pub. Serv. Corp., 84 FERC 61,194 (1998). See also Philadelphia Elec. Co., 15 F.E.R.C. 61,264 (1981) ("[W]e did not mean by this order [accepting a wholesale contract] to prejudge, for our own purposes or those of the respective state commissions, a determination of the prudence of either party in entering into this transaction"); Southern Company Services, Inc., 26 F.E.R.C. 61,360 (1984) ("[T]he Commission is not empowered to disapprove or modify a power sales agreement on the grounds that the buyer may not be making the best possible deal . . .. [T]he question of the prudence of a utility's power purchases is properly an issue in the buying utility's rate case where it seeks to pass the costs of its purchased power on to its ratepayers"); Southern. Co. Services, Inc., 20 F.E.R.C. 61,332 (1982)(same); Minn. Power \& Light Co. and Northern States Power Co., 43 F.E.R.C 61,104 at 61,34243, reh'g denied, 43 F.E.R.C. 61,502, order denying reconsideration, 44 F.E.R.C. 61,302 (1988); Palisades Generating Co., 48 F.E.R.C. 61,144 at 61,574 and n.10 (1989). 
"As a general matter, states have broad powers under state law to direct the planning and resource decisions of utilities under their jurisdiction. States may, for example, order utilities to build renewable generators themselves or deny certification of other types of facilities if state law so permits. They also, assuming state law permits, may order utilities to purchase renewable generation. States also may seek to encourage renewable or other types of resources through their tax structure or by giving direct subsidies. ${ }^{47}$

\section{FERC preemption precedent needs clarification and/or adjustment}

In several cases, FERC has found that state laws establishing purchase prices for wholesale transactions were preempted by the Federal Power Act. These cases do not explicitly preclude state-level feed-in tariffs, which are designed as offers. There is, arguably, an essential legal boundary between (a) the state ordering the utility to offer to buy at a state-set price and (b) the state ordering the utility to enter into a contract at a state-set price. This report argues that only the latter are preempted. In the two FERC cases described below, the state attempted to set the contract price by requiring the utility to enter into a contract at that price; in neither case did the state require the utility merely to offer to buy at a state-specified price. There is, however, no FERC precedent affirming this distinction. Until FERC creates that precedent, there will be uncertainty about the lawfulness of state feed-in tariffs outside of PURPA, even if those tariffs are framed as offers subject to final FERC approval.

a. Connecticut Light \& Power: A Connecticut statute required retail utilities to purchase electric energy generated by a resource recovery facility, owned or operated by or for the benefit of a municipality, at the same rate the utility charges the municipality for retail electricity. Applying the statute, the Connecticut Department of Public Utility Control (DPUC) ordered the utility to enter into a contract at that price.

FERC viewed the state statute as setting a rate for wholesale sales, thus entering FERC's exclusive domain. As FERC stated: "[T]he Municipal Rate Statute at issue here cannot be applied to require particular rates for sales from facilities that are not QFs but are sales by public utilities at wholesale in interstate commerce because the rates for such sales are subject to exclusive Commission jurisdiction." 48

By commanding the utility to buy wholesale power at a state-set price, the statute placed the utility in an impossible position: it would be unable to comply simultaneously with the rate set by the Connecticut DPUC and a different rate set by FERC. This potential for conflict means that the FPA must preempt the state statute.

47 Southern California Edison Co., 71 FERC para. 61,269 (1995).

48 Conn. Light \& Power, 70 FERC para. 61,012 (text accompanying n.60) (emphasis added). 
This potential for conflict disappears if the feed-in tariff is a state-mandated offer to buy at the state-approved price rather than a command to enter into a contract at that price. If a renewable seller accepts the offered rate and FERC changes the rate in approving the contract, the utility does not risk noncompliance with the state requirements. The utility meets its state obligation by offering to buy at the state established price; it meets its FERC obligation by purchasing at whatever rate FERC approves. This offer approach makes the state-level tariff very different from a European-style tariff, however, and constitutes a departure from the working definition set forth at the beginning of this report.

b. Midwest Power Systems: In Midwest Power Systems, ${ }^{49}$ FERC considered whether the FPA preempted an Iowa statute similar to the Connecticut statute. The statute authorized the Iowa Utilities Board to (a) order Iowa electric utilities to enter into contracts to purchase electricity from a class of alternative facilities defined by statute and (b) set rates for these transactions.

FERC reasoned that the FPA did not preempt a state law ordering utilities to purchase from state-designated facilities. As in Connecticut Light \& Power, however, FERC held that the FPA preempted the Iowa Utilities Board's orders to the extent they set rates for wholesale transactions. For the same reasons discussed above, a state-mandated offer, rather than a state-mandated transaction, should not be preempted. Neither Connecticut Light \& Power nor Midwest speaks to this distinction.

c. Consolidated Edison v. Public Service Commission of New York: In 1981, New York passed a law prescribing a minimum purchase price of 6 cents/kWh for electricity purchased by utilities from either a PURPA-certified QF, or a state-certified entity. The New York Commission ordered ConEd to offer to purchase electric energy from these entities at the statutory price. The New York Court of Appeals (the state's highest court) invalidated the statute. ${ }^{50}$ The Court framed the issue as:

"whether Part II of the Federal Power Act (FPA) preempts the [public service commission, or PSC] from compelling utilities to offer to purchase power from facilities that qualify only under the [state] Public Service Law. This court holds that it does." 51

According to the Court, the New York Commission offered this reasoning (paraphrased by the Court):

4978 FERC para. 61,067 (1997).

50 Consolidated Edison Comp. of New York v. Pub. Serv. Comm. of New York, 63 N.Y.2d 424, 472 N.E.2d 981 (1984).

51 Consolidated Edison, 63 N.Y. 2d at 438, 472 N.E.2d at 987. 
"The FPA only concerns regulations of sales and therefore, only the seller. Thus... the PSC's attempt to regulate a utility's purchase rate is merely a permissible regulation of the purchaser which Congress intended to leave to the States." 52

The court rejected the New York Commission's distinction between a purchase and a sale:

"While facially appealing, the argument distinguishing the admittedly preempted regulation of sellers of wholesale electricity (on-site generators) from purchasers in the same transactions (the utilities) is upon closer examination, untenable. Such a distinction would simply achieve indirectly that which is not permitted directly (see Northern Gas Co. v. Kansas Comm., 372 U.S. 84, 91-93). In Northern Gas Co., a State's attempt to require interstate pipeline companies to purchase gas ratably from local, State wells was rejected as an indirect attempt to impermissibly regulate wholesale prices of natural gas in interstate commerce, which could seriously impair FERC's ability to regulate in the field. ${ }^{53}$

It would clarify matters further for FERC to state that a state-mandated offer does not "achieve indirectly that which is not permitted directly" because the offer does not limit FERC's decision-making discretion. That clarification would reduce uncertainty for those outside New York concerned that their state courts might follow the New York court. Clarification also would allow New York to reconsider this issue should the question arise again in New York courts.

\section{Conclusions on the state role in wholesale price-setting}

This report has reasoned that a state relying on state law rather than PURPA (and therefore bound to take into account the FPA's preemptive intent) can take one of two actions:

1. The state can require the utility to offer to purchase at a state-set price, but the purchase is not executed until the contract is approved by FERC.

2. The state can require the utility to purchase, at a price set by FERC. What the state cannot do is require the utility to purchase at a state-set price $X$, a practice common to European-style feed-in tariffs. This third approach compels the utility to take an action (purchase at a state-set price) which FERC might forbid (by requiring a different price). A common error is to assert that because courts (and FERC) have emphasized the states' non-preempted role in guiding utility procurement, that this role includes an opportunity to require contracts at particular prices. It does not. Only FERC can set wholesale prices. The states can guide utility offers, and they can penalize or reward utility procurement decisions, but they cannot command wholesale contracts into existence. Only FERC can allow contracts to go

\footnotetext{
52 Id. at 439, 472 N.E.2d at 987.

53 Id. at 440, 472 N.E.2d at 988.
} 
into effect and then only after ensuring that the prices are just and reasonable. As already explained, FERC will find a contract price just and reasonable if, in the cost-based setting, the price recovers reasonable costs and reasonable profit; and in the market-based setting, if the seller has no market power. If a state believes that the FERC treatment leaves the seller with insufficient compensation, the state can supplement the price using the techniques described in Part I.D above (cash grants, renewable energy credits, tax credits and/or production-based incentive payments).

\section{In the FPA context, the state can set different sales offer prices for different technologies}

FPA Sections 205 and 206 require that wholesale rates be just and reasonable and not unduly discriminatory or preferential. The statutory concern is discrimination by the seller (not the buyer), because the FPA regulates sales (not purchases); its purpose is to protect buyers (not sellers). See Public Systems v. FERC, 606 F.2d 973, 979, n.27 (D.C. Cir. 1979) (the Federal Power Act is a consumer protection statute). A utility buyer that offers to pay different prices for different products does not trigger any statutory concern. FERC will view each seller on its individual merits, i.e., whether the price reflects reasonable cost (under cost based pricing); or, whether the seller has market power (under market-based pricing). Since costs differ among technologies, it is natural to have different prices in the cost-based pricing world. There is nothing new here; generating plants based on gas, coal and nuclear sell at different prices when they sell under the cost-based rate regime.

\section{Once states establish feed-in tariffs, sellers still must obtain FERC permission to sell}

If one views the state-level feed-in tariff as the utility's offer to buy at the state-set price, the seller must take certain actions to convert that offer into a transaction that complies with the Federal Power Act. There can be no sale at wholesale without FERC approval. Under present FERC practices, there are two distinct paths available to the seller: contract-by-contract approval and blanket advance approval. 


\section{Contract-by-contract approval (cost-based rates)}

Under this approach, the seller executes a service agreement with the buying utility, and then submits that agreement to FERC for approval. (The form of the service agreement could be part of the standard tariff.) For these agreements, FERC usually examines whether the rate reflects prudent costs and a reasonable rate of return. The seller must supply its cost information publicly. FERC issues a public notice of the seller's application. If there is no opposing intervenor, approval occurs within a few months. If there is opposition, the proceeding could involve either paper proceedings (parties file comments) or formal hearings before an administrative law judge (witnesses file testimony and appear for cross-examination) at FERC's discretion. These proceedings can take up to a year or more, during which time FERC can authorize sales to occur at the initially proposed price, but that are subject to refund should FERC ultimately order a lower price.

\section{Blanket advance approval (market-based rates)}

FERC will grant a seller advance approval to sell at any price it can negotiate, without the need for contract-by-contract review, if the seller proves that it lacks "market power" or that it has adequately "mitigated" any market power it does have. ${ }^{54}$ FERC reasons that the absence of market power means that competitive forces will keep rates just and reasonable and not unduly discriminatory as required by the FPA. ${ }^{55}$ A seller that obtains this blanket approval does not need FERC permission for each contract.

To obtain approval, the seller must submit a technical analysis addressing multiple FERC "screening" tests. ${ }^{56}$ The seller has the burden of proof. The generation market power test, for example, requires a seller to pass two screens. The "pivotal supplier screen" assesses whether the supplier controls an amount of capacity that is "pivotal"-indispensable to the marketbecause it exceeds the difference between the market's available capacity and the market's demand. A supplier who controls indispensable capacity could raise and sustain its price above just and reasonable levels; that is why it would fail this screen. A seller fails the "market share screen" if its share of total market capacity exceeds 20 percent. ${ }^{57}$ An applicant seller that fails

${ }^{54}$ FERC has defined market power as a seller's ability to "significantly influence price in the market by withholding service and excluding competitors for a significant period of time." Citizens Power \& Light Corp., 48 FERC 61,210 at 61,777 (1989) (granting approval to power marketer for market based rates).

${ }^{55}$ California v. FERC, 383 F.3d 1006, 1013 (9th Cir. 2004) (finding that market based rates are lawful, based on prior finding of lack of market power and post-approval reporting requirements).

56 18 C.F.R. 35.37.

$57 \quad 18$ C.F.R. $35.37(\mathrm{a})(2)$. 
either screen can offer alternative evidence that it lacks market power. A seller that received market pricing approval (after passing the screens) must submit a new market test every three years, along with other reports that enable FERC to verify that no factual changes have caused the seller to gain market power.

Even small sellers can have market power, if for example, (a) the geographic market is constrained because of transmission shortages (meaning buyers have limited access to alternative supplies) and/or (b) the state's tariff has defined the product so narrowly that the seller has a high market share or is "pivotal." If the seller has market power, FERC will deny blanket approval. The seller still can sell, but its price will be subject to FERC's cost-based pricing review procedures on a contract-by-contract basis. FERC will cap the price-either on a cost basis or at the level FERC believes is the proper market price.

While a detailed description of FERC's market power tests falls outside the scope of this report, policymakers should be alert to a number of uncertainties for renewable sellers. First, where the state sets the offer price without regard to competitive forces, opponents can argue that the price fails the FPA's just and reasonable requirement. (For that reason, some have proposed competitive bidding procedures as a way to establish the feed-in tariff prices.) Second, consider a state-set tariff requiring the utility to offer different prices for different power sources. It is not clear how FERC will define the "market" for purposes of determining whether a seller has market power. If FERC uses a narrow tariff definition of the product (e.g., "solar power" as opposed to "all power"), and if there are few sellers willing and able to sell solar, the screening tests could cause a failure for the solar seller seeking blanket permission to sell at market-based rates.

Here is a variation on the same problem: Assume the state commission has declared that the retail utility must purchase a specified quantity of wind power by a specified date. Suppose further that this mandatory purchase quantity exceeds the available supply. That fact means that each supplier is indispensable to the state's goals. An indispensable supplier is a supplier with market power. FERC thus will be concerned about the reasonableness of the price. It is true that the state commission will have constrained the seller's market power by fixing the offer price (rather than having allowed the seller to extract a higher price by withholding its supply). But, the state-set offer price itself could exceed the price that would prevail if there were surplus supply because the state would have set the price high enough to attract the limited number of willing sellers. In this context, FERC could find market power and thus disapprove the sale price even though the state commission was willing to have its consumers pay the price.

One more complicating factor: Some states with renewable purchase obligations allow the utility to make an "alternative compliance payment" (ACP) in lieu of purchasing from a renewable seller. ${ }^{58}$ Before FERC makes a finding of seller market power, it would need to take into account the price-disciplining effect of the buyer's option. The seller will not be able to raise its price above the ACP level and still make a sale.

58 See Part I.D.1 above for an explanation of "alternative compliance payment." 
This uncertainty about the lawfulness of the sales price raises this question: are there other ways to ensure the justness and reasonableness of market prices in the context of statemandated feed-in tariffs? One possibility is for FERC to consider cost-based safe harbors, presumptions, or other guidance as a way to clarify the circumstances under which renewable sellers can sell. See Part II.F below.

\section{Supplemental compensation from the state}

A seller whose application to FERC (either for cost-based prices or market-based prices) is rejected must limit its price to the FERC-approved cost-based price. If this compensation is insufficient, the seller could seek from the state any of the types of supplemental compensation described in the PURPA discussion at Part I.D above (i.e., cash grants, RECs, tax credits for the purchasing utility, or production-based incentive payments). The same FERC reasoning that allowed these supplements in addition to avoided cost (because the supplements are not "controlled by PURPA," see American Ref-Fuels above) should apply in this FPA context as well. Because FERC has not expressly established that the PURPA mechanisms described in Part I.D are available under the FPA, states and practitioners should consider asking FERC to confirm this point.

\section{Must the seller in a state law-based regime still comply with PURPA's avoided cost cap?}

This subsection argues that when the utility's purchase obligation arises from state law rather than PURPA, PURPA's avoided cost cap does not apply because PURPA does not apply. FERC precedent, however, is at odds with this conclusion. After discussing the arguments for, and FERC's precedents against, this conclusion, the authors of this report suggest ways for FERC to re-interpret or modify its precedent to facilitate state-level tariffs. If FERC maintains its precedents, states still can grant sellers compensation exceeding avoided cost through the means described in Part I.D above (although FERC clarification would be useful on this point).

a. Alternative interpretation: PURPA language does not support the application of the avoided cost cap to a state-law based, non-PURPA regime: However, FERC precedent does not agree with this alternative interpretation. Section 210(b)(1) of PURPA, 16 U.S.C. sec. 824a-3(b)(1), states (emphasis added):

"The rules prescribed under subsection (a) [requiring utilities to purchase from QFs] shall insure that in requiring any electric utility to offer to purchase electric energy from any $[\mathrm{QF}]$, the rates for such purchase shall be just and reasonable...."

"No such rule prescribed under subsection (a) shall provide for a rate which exceeds the incremental cost to the electric utility of alternative electric energy." 
The italicized language indicates that the prohibition against above-avoided cost rates applies to prices set pursuant to the mandate of "subsection (a)", i.e., Section 210(a) of PURPA. That provision requires FERC to issue rules requiring utilities to buy from QFs. When the "requiring" law is not PURPA, i.e., when the requirement flows from state law, the language, by its terms, does not apply.

That an entity happens to be a QF does not affect this reasoning provided that the utility's obligation to buy comes from state law rather than PURPA. Nothing in PURPA's statutory language or history conflicts with this conclusion or suggests that an entity's QF status deprives it of non-PURPA, state law privileges. But, FERC precedent comes to the opposite conclusion, as discussed next.

b. FERC's precedent: Connecticut Light \& Power Co., 70 FERC para. 61,012 (1995), order denying reconsideration, 71 FERC para. 61,035 (1995), involved a state statute requiring utilities to buy power from municipal resource recovery facilities "at the same rate that the utility charges the municipality for electricity."

Addressing the utility's challenge to the statute, FERC found that when the seller is not a QF, the FPA preempts on the grounds that the statute sets wholesale rates, which is FERC's exclusive domain. ${ }^{59}$ And if the seller is a QF, FERC reasoned, PURPA preempts to the extent the statute authorizes rates above avoided costs. FERC then confronted directly the question whether a state law that required utility purchases independent of PURPA could authorize prices above avoided cost:

"We recognize that the Commission seems to have suggested, in 1980, in the preamble to its regulations, that, notwithstanding PURPA's clear mandate, the states could exercise state authority independent of PURPA to impose a rate exceeding avoided cost:"

The Commission then quoted two paragraphs from that 1980 Preamble:

"The Commission has become aware that several States have enacted legislation requiring electric utilities in that State to purchase the electrical output of facilities which may be qualifying facilities under the Commission's rules at rates which may differ from the rates required under the Commission's rules implementing section 210 of PURPA."

"The Commission has set the rate for purchases at a level which it believes appropriate to encourage cogeneration and small power production, as required by section 210 of PURPA. While the rules prescribed under section 210 of PURPA are subject to the statutory parameters, the States are free, under their own authority, to enact laws or regulations providing for rates which would result

${ }^{59}$ Part II.B.3 discussed this aspect of the case. 
in even greater encouragement of these technologies. However, State laws or regulations which would provide rates lower than the federal standards would fail to provide the requisite encouragement of these technologies, and must yield to federal law. If a State program were to provide that electric utilities must purchase power from certain types of facilities, among which are included "qualifying facilities," at a rate higher than that provided by these rules, a qualifying facility might seek to obtain the benefits of that State program. In such a case, however, the higher rates would be based on State authority to establish such rates, and not on the Commission's rules." ${ }^{60}$

FERC then, in its $C L \& P$ order (at n.45) distanced itself from its 1980 statements:

"This [Preamble] language is, in fact, ambiguous. First, as the Commission expressly acknowledged, the ability of a QF to obtain rates in excess of avoided cost depends on the state's authority independent of PURPA and this Commission's regulations to set such rates. This language leaves unaddressed and undecided whether and when states may, in fact, have authority to set such rates. Second, in language that immediately precedes the language quoted above, the Commission explained that section 210(b) of PURPA provides that "in requiring any electric utility to purchase electric energy from a $[\mathrm{QF}]$, the Commission must ensure that the rates. . . not exceed the incremental cost of alternative electric energy (the costs of energy to the utility, which, but for the purchase, the utility would generate itself or purchase from other source)." Id. There is obvious inconsistency in the Commission seemingly simultaneously deciding that states both may (in the language quoted in the text) and may not (in the immediately preceding language) require rates in excess of avoided cost."

FERC then added (at text accompanying n.46):

"However, the Commission did not provide any rationale to support this statement or any legal analysis. We cannot ascertain at this date any legal basis under which states have independent authority to prescribe rates for sales by QFs at wholesale that exceed the avoided cost cap contained in PURPA. Moreover, for states to mandate rates above avoided cost for a particular class of power suppliers (i.e., QFs) also runs counter to Congress' and the Commission's current policies which strongly favor competition among all bulk power suppliers."

In other words, in Connecticut, FERC clearly stated that a state law could not require utilities to purchase wholesale power at prices above avoided costs, even if that state requirement was established independent of PURPA.

In Midwest Power Systems, Inc., 78 FERC para. 61,067 (1997), FERC followed its Connecticut Light \& Power decision. An Iowa statute required utilities to purchase power from

${ }^{60}$ FERC Stats. \& Regs., Regulations Preambles 1977-1981 at 30,875. 
state-defined "alternate energy production facilities," at rates set by the Iowa Board. The statute stated that the facilities could be either QFs or non-QFs. The Iowa Board ordered a utility to enter into contracts with two wind suppliers at rates in excess of the utility's avoided cost. The two wind suppliers were not QFs; they had neither self-certified as QFs nor sought QF certification from FERC. FERC found that PURPA did not preempt the state from enacting laws to compel utilities to purchase from renewable suppliers. But as in Connecticut Light \& Power, "the orders of the Iowa Board are preempted to the extent that they require rates to QFs in excess of the purchasing utilities' avoided cost, and to the extent that they set rates for the wholesale sales of electric energy by public utilities."

The Commission continued:

"We do not agree with the intervenors' efforts to distinguish the Connecticut case from the instant case on the basis that the Iowa statute was adopted independently of PURPA. The conclusions reached in the Connecticut case are not dependent on whether the facilities are QFs or whether the state is invoking its obligations under PURPA. Even if the alternative facilities at issue are not QFs, the orders of the Iowa Board implementing the Iowa statute are preempted by federal law to the extent they set rates for wholesale sales by public utilities of electric energy in interstate commerce."

The last sentence of this passage implies that in the case of a state mandate based on state law, the preempting statute is the FPA (which addresses "rates for wholesale sales by public utilities of electric energy in interstate commerce"). However, elsewhere in Midwest, FERC finds that PURPA applies and preempts a price exceeding avoided cost, in the case of a state statute mandating the purchase.

If a state's utilities have received a FERC exemption from their PURPA purchase obligation, could there still be a PURPA avoided cap on a state-mandated offer? Where FERC has exempted a utility from its PURPA purchase obligation (as discussed at Part I.C above), a state seeking to implement feed-in tariffs will need to turn to its own statutory authority to mandate utility purchases. ${ }^{61}$ At the same time, some entities eligible to sell under these state feed-in tariff programs might want to retain QF status so as to obtain PURPA-mandated interconnection rights (if they viewed these rights as preferable to the interconnection rights available under the FPA), or to avoid FPA price regulation (as explained in the next subsection, FERC has exempted QFs $20 \mathrm{MW}$ and below from price regulation under FPA Sections 205 and 206). In these situations, i.e., where there is no PURPA utility purchase obligation, FERC's $C L \& P$ and Midwest precedents, (i.e., applying PURPA's avoided cap even when the purchase obligation comes from state law) should not apply. However, FERC has not

${ }^{61}$ Recall from Part I.C that FERC regulations allow the QF to "tag" utilities other than the QF's host utility with a PURPA purchase obligation, should that host utility have received a FERC exemption from the purchase obligation. The paragraph in the text assumes that a state has determined that these remaining QF options are insufficient outlets to produce the desired amount of renewable energy. 
addressed this question in the context of a utility exempted from the PURPA purchase obligation. It would be useful if FERC clarified that its $C L \& P$ and Midwest precedents do not apply to QF sales to utilities under state law where FERC has exempted the utility from its PURPA purchase obligation. This clarification would ensure that states could set offer prices exceeding avoided cost. However, the seller still would have to obtain FERC permission under the FPA.

\section{E. Exemptions from FPA review for QFs sized $20 \mathrm{MW}$ and below if FERC clarifies and/or adjusts its precedent}

PURPA directed FERC to prescribe rules under which QFs are "exempted in whole or part from the Federal Power Act" if FERC determines such exemption is necessary to encourage cogeneration and small power production. 16 U.S.C. 824a-3(e). In Order No. 697-A, ${ }^{62}$ FERC described the circumstances under which QF sales are exempt from Section 205:

"All sales of energy or capacity made by QFs $20 \mathrm{MW}$ or smaller are exempt from section 205. Sales from a QF larger than $20 \mathrm{MW}$ are exempt from section 205 only if those sales are made pursuant to a state regulatory authority's implementation of PURPA, or if those sales are made pursuant to a contract executed on or before March 17, 2006 (unless the sale is from a qualifying small power production facility with a power production capacity which exceeds 30 MW, if such facility uses any primary energy source other than geothermal resources, in which case the sale is not exempt)."63

\section{If FERC adjusts its precedents, QFs $20 \mathrm{MW}$ and below could sell under state feed-in} tariffs free of FPA review: If FPA Sections 205 and 206 do not apply to sales by QFs sized 20 MW and below, states should be able to create feed-in tariffs (framed as offers to buy and rooted in state law rather than PURPA) for these sellers, where no seller need obtain contract approval from FERC or comply with PURPA's avoided cost cap. This result would make the state feed-in tariff like the European-style model - where the transaction can occur by virtue of the tariff alone, without any further regulatory approval.

${ }^{62}$ Market Based Rates For Wholesale Sales Of Electric Energy, Capacity And Ancillary Services By Public Utilities, Order No. 697, 119 FERC 61,295 (Jun. 21, 2007), order on rehearing and clarification, Order No. 697A, 123 FERC 61,055, 2008 FERC LEXIS 788 at *548 (Apr. 21, 2008)(describing exemptions from Section 205 in the context of explaining process by which QFs can seek market based rates); Revised Regulations Governing Small Power Production and Cogeneration Facilities, Order No. 671, 115 FERC 61,097, order on rehearing, Order No. 671-A, 115 FERC 61,225 (2006) at text and n.17 (explaining that "20 MW threshold strikes a reasonable balance by protecting the smallest facilities while ensuring that sales by larger QFs are subject to Commission oversight" and further, is consistent with the 20 MW size limit for small generating facilities found in Order No. 2006 (Standardization of Small Generator Interconnection Agreements and Procedures)).

63 Order 697-A is codified in FERC regulations as 18 C.F.R. 292.601. See Appendix B. 
The foregoing analysis faces real uncertainty, however, because of the FERC's Connecticut Light \& Power and Midwest Power cases. Those cases, as explained above, hold that if an entity has QF status, FERC will apply PURPA's avoided cost cap even if the utility's obligation to purchase arises from state law rather than PURPA. It would be helpful for FERC to clarify whether QF status caps the utility's purchase obligation at the avoided cost when the purchase obligation is a state law obligation rather than a PURPA obligation. A finding of no cap, in the context of a state law mandate, would be logical because it would put the QF in the same position as non-QFs in terms of ability to sell outside of PURPA (i.e., being free from the avoided cost constraint).

\section{F. Safe Harbors, Presumptions and other Forms of Guidance: FERC can facilitate sellers' compliance with the Federal Power Act}

State commissions and sellers will find the FPA requirements inconsistent with a European-style tariff in which the tariff alone both invites and consummates a transaction without the need for further regulatory review. Part II.A above explained that the FPA requires the price of all wholesale sales to be "just and reasonable." In FERC's cost-based practices, a just and reasonable rate is one that allows recovery of prudent costs plus a reasonable return. In FERC's market-based rate practices, a just and reasonable rate is any rate charged by a seller that FERC has determined lacks market power. This subsection discusses ways to modify current FPA procedures so that state-level feed-in tariffs resemble the European model more.

Based on an investigation of cost parameters, FERC could establish safe harbors, rebuttable presumptions, or other forms of guidance such that state-mandated offer prices consistent with these pronouncements would constitute "just and reasonable" prices for the defined products, project sizes, and geographic regions. FERC then would issue a rule stating that a wholesale sale under a state-set tariff consistent with those safe harbors and other guidance automatically complies with the FPA.

Because costs will vary by regions, will change over time, and will vary by scale, ownership and other factors, it is worth considering several possible processes by which FERC could establish these guidelines. One approach would be for individual states to seek a FERC ruling declaring that their state's proposed tariff prices to be just and reasonable, thereby relieving sellers of an obligation to seek FERC approval of contracts entered into under those tariffs. Another approach would be for FERC to establish prices for a particular region if there was a commonality of cost experience within that region.

If designed well, the FERC safe harbors and guidance would not be preemptive of state efforts. Either approach would obviate contract-by-contract approvals under the FERC's cost-based rate procedures as well as market power screening under FERC's market-based rate procedures. States would be free to establish higher prices for utility offers (provided they were offers, not commands to enter into contracts - see Part II.B above), subject to the seller's obligation to seek FERC approval for the resulting contract. Some routine filings by the seller 
still might be necessary to comply with the 1935-era filing provisions of the Federal Power Act, but the filing requirements could be minimal.

Some might question this approach on the grounds that renewable prices exceeding generic market prices are inherently unjust and unreasonable. In other words, some might argue that the pricing does not comport with FERC precedent for determining just and reasonable pricing because it would neither be the result of competitive market forces nor be based on a contract-by-contract review of costs. One response is as follows: In the context of cost-based regulation, FERC sets prices based on reasonable cost. That a nuclear power plant's embedded cost exceeds that of a natural gas plant does not make the former's wholesale price unreasonable. The same reasoning applies to a situation in which renewable seller's price exceeds that of a non-renewable seller. As long as the price for the given product is based on its reasonable cost, that product's higher price compared to other higher-cost products is not fatal to its lawfulness. FERC presently has two distinct pricing regimes: cost-based and market-based. While evaluation of market prices takes into account cost-based benchmarks and vice versa, FERC has never said that one type of benchmark is binding on the other. Very different prices for electricity co-exist today, all under the "just and reasonable" umbrella. Further, even if FERC were to find particular price levels unjust and unreasonable, the state can limit the required purchase payment price to the FERC-determined just and reasonable level and then supplement that price with state-jurisdictional cash payments, RECs, tax credits or performance-based incentive payments (as discussed in the PURPA context in Part I.D above, which should be applicable in the FPA context, as described in Part II. D. 3.).

Because there is no recent FERC experience with this type of approach, an administrative inquiry and rulemaking process would be necessary. ${ }^{64}$ From a procedural perspective, consideration of this safe harbor/rebuttable presumption approach can be initiated by:

1. FERC - who would initiate a rulemaking proceeding aimed at declaring safe harbor price ranges for various sizes, technologies and geographic areas;

2. A renewable seller or group of sellers - who would submit a request for a FERC determination of safe harbor prices; or

3. A state commission or group of state commissions - who would petition FERC to (a) initiate a generic proceeding on safe harbors for the nation, a region, or a group of utilities within a particular state and (b) find that a specified set of prices for sales from particular types of projects to utilities satisfy FERC's standards for either cost-based pricing or market-based pricing.

64 In another era, FERC's predecessor, the Federal Power Commission, seeking to reduce the delays and workload associated with setting rates company by company, established "area rates" for natural gas sales by producers. A producer located in a particular area could sell at those rates without having to demonstrate that its costs justified the rates. Legal challenges to the FPC's approach took many years and culminated in a U.S. Supreme Court decision upholding the FPC's authority. See Permian Basin Area Rate Cases, 390 U.S. 747 (1968). 
In addition to establishing cost-based safe harbors, it would be helpful to renewable energy developers and state policy makers for FERC to clarify how its market power tests would apply to renewable generators under various circumstances. The types of questions that can arise include:

1. How will FERC determine the product market boundaries when a state has mandated utility purchases of specific quantities of specific types of power (e.g. solar, wind, hydroelectric)?

2. Will FERC view state-authorized "alternative compliance payments" as disciplines on the market prices?

3. How will FERC determine geographic market boundaries for different types of renewable sellers?

4. Where a seller fails one or both of the market power screens (e.g., pivotal supplier test and market share test), what mitigation actions will FERC require or authorize?

Figure 1 provides a single-page summary of the existing path for non-preemption under PURPA and the path for non-preemption under state law (if FERC changes existing precedent). 
Legal Basis for the State Order:

Public Utility Regulatory Policies Act (PURPA)

\section{Key Legal Features of this Path}

1. Seller must be qualified facility (QF) - self-certified or Federal Energy Regulatory Commission (FERC) certified.

2. State orders utility to buy at the state-set price, which must equal utility's "avoided cost."

3. Seller is exempt from Federal Power Act (FPA)

Result: Clear path to a feed-in tariff (FIT): Utility must buy at the state-set tariff price; no FERC approval of the sale is necessary.

What if the "avoided cost" price provides insufficient revenue to generators? Under FERC's American Ref-Fuels precedent, state can create two-part payment:

\section{Avoided + Supplement (outside of PURPA)}

cost

1. Order the utility to buy renewable energy (required certificates (RECs) from the QF; and/or

by PURPA) 2. Provide the QF grants or incentive payments (funded by rates or taxes: and/or

3. Set the utility-paid price above avoided cost but grant the utility tax credit equal to the above-avoided cost increment.

\section{Caution}

This PURPA path does not work if FERC has exempted the host utility from its PURPA purchase obligation (see 16 U.S.C. $824 a-3(m)(1)(A)-(C)$, added by EPAct 2005), unless the QF can "tag" another utility, via host utility's Order 888 tariff or regional transmission organization's (RTO's) regional tariff. If the PURPA path fails, state must act under state law. See the right side of the diagram.

\section{Legal Basis for the State Order: State Statute}

(Subject to Federal Power Act - FPA)

\section{Key Legal Features of this Path}

1. Seller can be $Q F$ or non-QF.

2. Seller of power will become a "public utility" under the FPA (unless in Alaska, Hawaii, or most of Texas). Seller must prove its price satisfies FPA's "just and reasonable" standard. QFs $<20$ MW would be exempt if FERC changes existing precedent (see Caution-2* below).

3. Under FERC's Connecticut Light and Power (CL\&P) case, state cannot command utility to buy at the state-set price (i.e., FERC precedent must be changed). Author's view on path forward: FERC changes precedent such that state must order utility to offer to buy at the state-set price, subject to FERC approval.

\section{To meet FPA's just and reasonable standard, seller has two options}

\section{Cost Basis}

FERC undertakes price-cost review, contract-by-contract. FERC approves the contract if the price recovers no more than prudent costs plus a reasonable return on equity

\section{Market Basis}

FERC market power review, seller-by-seller Seller submits technical study every three years If FERC finds no seller "market power," FERC grants seller blanket approval to enter contracts at will, at any price."

\section{Question: Instead of contract-by-contract and seller-by-seller} reviews, can/will FERC create safe harbors for sellers' prices?

What if the "just and reasonable" price provides insufficient revenue to generators?

If state-desired price exceeds the FPA's "just and reasonable" price, the state may be able to provide supplemental payments, as it can under PURPA. (Authors' view; no FERC precedent - although there is PURPA precedent.) See second box, left-hand side.

\section{Caution}

Until FERC modifies or clarifies its CL\&P precedent

1. Avoided cost cap appears to apply to QFs and non-QFs;

2. QFs $20 M W$ and below, selling under a state law mandate, are capped at avoided cost. If FERC changes existing precedent and they are not capped, then there is a second clear path for FITs: QFs sized 20 MW and below, selling under a state law mandate, would be free of both PURPA (because they sell under state mandate, outside PURPA) and the FPA (because FERC exempted them).

\section{Figure 1. Can a state order its utilities to file "feed-in tariffs"? Two paths to non-preemption}




\section{Amendments to Current Federal Statutes}

Up to this point, this report has discussed current federal law: the conditions under which it prevents states from promulgating feed-in tariffs that, by themselves and without any federal review, could entitle sellers to sell wholesale renewable power at rates sufficiently high to attract state-desired technologies. Part III looks at possible amendments to federal law that would achieve this objective. ${ }^{65}$ First, a provision in the American Clean Energy and Security Act is addressed as passed by the U.S. House of Representatives in June 2009. Then, four conceptual legislative options are discussed that could clarify the role of renewable energy feed-in tariffs in the United States.

\section{A. The House-Passed American Clean Energy and Security Act}

On June 26, 2009, the U.S. House of Representatives passed the American Clean Energy and Security Act. ${ }^{66}$ Section 102, entitled "Clarifying State Authority to Adopt Renewable Energy Incentives," drafted as an amendment to PURPA, provides:

"Notwithstanding any other provision of this Act [PURPA] or the Federal Power Act, a State legislature or regulatory authority may set the rates for a sale of electric energy by a facility generating electric energy from renewable energy sources pursuant to a State-approved production incentive program under which the facility voluntarily sells electric energy. For purposes of this subsection, State-approved production incentive program means a requirement imposed pursuant to State law, or by a State regulatory authority acting within its authority under State law, that an electric utility purchase renewable energy (as defined in section 609 of this Act) at a specified rate." 67

The Energy and Commerce Committee's section-by-section summary explains that the proposed language is meant to remove a perceived barrier to implementing feed-in tariff and production incentive programs:

"[N]otwithstanding any provision to the contrary in [PURPA], any state may establish rates to be paid by state-regulated utilities intended to provide incentives

${ }^{65}$ The authors of this report do not necessarily support these amendments or their underlying purpose. Our assignment is to analyze the terrain, not advocate for an outcome.

${ }^{66}$ American Clean Energy and Security Act, H.R. 2454, 111th Cong. (2009) available at http://www.govtrack.us/congress/billtext.xpd?bill=h111-2454 (last visited November 29, 2009).

${ }^{67}$ Section 609 of PURPA defines renewable energy as including: wind; ocean waves; biomass; solar; landfill gas; incremental hydropower; livestock methane; or, geothermal energy. Section 609 is codified at 7 U.S.C. 918c(a)(3)(4) (relating to issuance of rural and remote communities electrification grants). 
for development of renewable energy. In the past, some have interpreted PURPA to bar such incentive rates to the extent they exceed the avoided cost of power a utility could generate or procure from any other source, denying states the ability to account for the additional benefits of renewable energy." 68

Therefore, it appears that the goal of this provision is to eliminate the PURPA and FPA preemptive effects discussed in this report. However, there is need for care and additional clarification in interpreting this provision's effect on each of the two statutes. Specifically:

PURPA: The proposed language had not adequately addressed PURPA's two main features: its utility obligation to purchase and its avoided cost cap. While it is clear that the proposed language would free states to set prices above avoided cost, it is not clear whether the purchase mandate accompanying those prices would be a PURPA mandate or a state law mandate. It appears, at the least, that the provision would allow a state to establish a state law purchase mandate and set prices above avoided cost - a result that would overrule Connecticut Light \& Power and Midwest Energy. (Recall that Part II.B.3 above expressed concern that FERC appeared to bar, on PURPA preemption grounds, state-set offer prices grounded in state law rather than PURPA).

FPA: If the provision's intent is to free the seller from the FPA as well as from PURPA, it is not clear it has achieved this goal. To do so, it would allow states to set rates for wholesale sales by renewable energy facilities, an activity that the FPA currently vests in FERC exclusively. A seller under a state program would not need to seek FERC permission to sell, whether at cost-based prices or at market prices. The seller would be free, rather, to enter into any arrangement at any price. A state then can design a feed-in tariff like a European tariff, where the tariff itself, without any further regulatory action, creates simultaneously a utility duty to buy and a seller right to sell. It is not clear from the language whether the sellers would have to place their contracts - with the state-set rates - on file at FERC, as is required today of wholesale sales by entities that have not received market-based rate authority.

The language, in short, does not make clear whether the provision intends to (a) exempt the seller from having to comply with either federal statute in any way or, alternatively, (b) maintain the seller's obligation to comply with the statute but free the state to set the prices without preemption.

${ }^{68}$ Committee on Energy and Commerce, 111th Cong., The American Clean Energy and Security Act (H.R. 2454): Section-By-Section (Jul. 14, 2009) available at http://energycommerce .house.gov/Press 111/20090720/hr2454_sections mmary.pdf. 


\section{B. Four Conceptual Federal Legislative Options}

Four major categories of federal legislative action could provide, to varying degrees, additional clarity regarding the implementation of feed-in tariffs at the state level. Critically, more than one legislative option could be implemented simultaneously. Each of these categories of action presents opportunities but involves limitations. Congress could:

1. (a) Maintain the present PURPA features of the retail utility's obligation to buy under PURPA and the state's obligation to set the PURPA prices but (b) lift the avoided cost cap for specified renewable technologies and sizes. Under a variation of this approach, Congress could reverse its EPAct 2005 amendment, which authorized FERC to exempt utilities from their purchase obligation upon a finding that QFs had competitive market options. (See Part I.C above).

2. Maintain renewable sellers' obligation to comply with all FPA contract-submission requirements (for non-QFs, operating outside of PURPA) but also provide that rates established by states pursuant to state-level feed-in tariffs (or production incentives) are deemed to satisfy the just and reasonable requirement.

3. Exempt renewable sellers (non-QFs, operating outside of PURPA) from the FPA entirely (meaning, no filing requirements, no rate approval requirements) for sales made pursuant to state-established, feed-in tariff programs.

4. Authorize (or direct) FERC to act in the three manners described above, under defined circumstances. Congress would spell out FERC's range of discretion or obligation.

In each of these alternatives, Congress could fine-tune its amendment by (a) specifying certain technologies, sizes, and quantities, (b) by capping the prices (or authorizing FERC to), or (c) by specifying a sunset date. 


\section{Related Questions}

In the course of peer review of this report, several questions arose that apply generally, and thus do not have a specific logical place in the document. These are discussed below.

\section{A. What price-setting methods are available to state designers of feed-in tariffs?}

Designers of feed in tariffs must answer this question: What price will attract renewable energy sellers at a desired quantity and diversity? There are a number of pricing options, ${ }^{69}$ including: (a) cost-based (the price recovers the typical cost of the technology at issue plus a reasonable profit); (b) value-based (the price reflects the value placed by the state's citizens on the power, where "value" can reflect the benefits of a cleaner environment, and/or a diverse power supply, among other objectives); and (c) market-based (the price is based on a competition among similar projects). There also are hybrid approaches, such as allowing rates to fluctuate with market prices subject to price floors, price ceilings or both, so as to increase revenue certainty for project owners sufficient to attract financing. Each of these options has the potential to exceed the utility's avoided cost (as required by PURPA) and/or the FERC's view of "just and reasonable" (as required by the Federal Power Act). It is the potential for this deviation - between the state-desired rate and the rate required by one or both federal laws - that requires care in addressing the intersection between state and federal law.

What about market-based auctions and other forms of competitive bidding? In the context of renewable energy policy, auctions and bidding play two possible roles. One role is to determine winners: who gets to sell to the utility. A state could use this "select-the-winner" approach to pick suppliers under a renewable portfolio regime. This approach differs from a feed-in tariff, which does not select winners; in a European-style feed-in tariff, every eligible entity has a right to sell. The second role is to determine price: The auction or bidding process discovers a price that otherwise would be set administratively. This price then can become the price used in a feed-in tariff. Analysis of the advantages and disadvantages of these options lies outside this report's scope. Under either option, the same jurisdictional questions and constraints arise: PURPA and the FPA play the same roles regardless of the price-setting method used.

\section{B. Does the applicability of the FPA or PURPA change if the seller's delivery to the buyer occurs at a distribution facility rather than a transmission facility?}

The answer is "no." FERC's wholesale sales jurisdiction does not vary with the facility over which the transaction occurs.

The FPA grants FERC exclusive jurisdiction over wholesale sales, even if those sales occur within the same state (except for Alaska, Hawaii and most of Texas). Wholesale sales are sales for resale. "Wholesale" is a commercial concept, not a physical concept. Wholesale sales

69 As described in Grace, Robert, W. Rickerson, K. Porter, J. DeCesaro, K. Corfee, M. Wingate and J. Lesser (KEMA), Exploring Feed-in Tariffs for California. California Energy Commission. Publication number: CEC-300-2008-003-F (November 2008). 
can take place over distribution systems exclusively, transmission systems exclusively, or both. ${ }^{70}$

As with the wholesale transactions under the FPA, the application of PURPA does not differ with whether the transaction occurs over distribution or transmission facilities.

\section{Do the federal statutes apply to renewable sales to retail customers?}

Retail electricity sales trigger none of the issues discussed in this report. The federal law constraints addressed here apply only to wholesale transactions. Retail transactions fall outside both federal statutes. States are free to establish programs allowing renewable generators to sell to retail customers. (These programs are not like the feed-in tariffs addressed in this report, because they do not create any obligation in the retail customer to buy from the generator). This state freedom includes the situation where a non-utility (e.g., $3^{\text {rd }}$ party system owner) sells power to a retail customer who is a participant in a net metering program. The retail customer's purchases from the non-utility seller cause the retail customer's meter to "run backwards," reducing his purchases from the utility. Provided there is no "net sale" during a billing cycle (a net sale would occur if the retail customer's purchases from the non-utility exceed the customer's usage during a billing cycle), FERC will treat the non-utility generator as making only retail sales, not wholesale sales; thus the FPA will not apply. FERC explained this reasoning in its Declaratory Order in SunEdison, 129 FERC para. 61,146 (Nov. 19, 2009).

70 See DTE Energy Co. v. FERC, 394 F.3d 954 (D.C. Cir. 2005) (noting that wholesale sales can take place over distribution facilities).

For readers interested in even more Federal Power Act detail, FERC's Order No. 888 established a seven-part test for determining whether facilities are transmission or distribution. The seven factors are: (1) Local distribution facilities are normally in close proximity to retail customers; (2) Local distribution facilities are primarily radial in character; (3) Power flows into local distribution systems; it rarely, if ever, flows out; (4) When power enters a local distribution system, it is not reconsigned or transported on to some other market; (5) Power entering a local distribution system is consumed in a comparatively restricted geographical area; (6) Meters are based at the transmission/local distribution interface to measure flows in the local distribution system; and (7) Local distribution systems will be of reduced voltage. Promoting Wholesale Competition Through Open Access Non-Discriminatory Transmission Services by Public Utilities; Recovery of Stranded Costs by Public Utilities and Transmitting Utilities, Order No. 888, FERC Stats. \& Regs. I 31,036 at 31,981 (1996), order on reh'g, Order No. 888-A, FERC Stats. \& Regs. \ 31,048, order on reh'g, Order No. 888-B, 81 FERC \ 61,248 (1997), order on reh'g, Order No. 888-C, 82 FERC $\mid 61,046$ (1998), aff'd in relevant part sub nom. Transmission Access Policy Study Group v. FERC, 225 F.3d 667 (D.C. Cir. 2000), aff'd sub nom. New York v. FERC, 535 U.S. 1 (2002). 


\section{Conclusions}

Not surprisingly, statutes enacted in 1935 (FPA) and 1978 (PURPA) do not apply neatly to market situations and feed-in tariff policy proposals in 2010. This report has described the complexities and uncertainties, and it has proposed options for their revision.

States seeking to mandate utility purchases of renewable power through a feed-in tariff can rely on PURPA or, provided FERC clarifies certain precedents, on state law. Each approach faces constraints arising from federal law; each approach has alternative paths.

States that rely on PURPA have a clear, non-preempted path for implementing feed-in tariff policies. They can craft a two-part payment where (1) power is paid for at the utility's avoided cost and where (2) additional payment is made through supplemental means (cash grants, RECs, tax credits and/or production-based incentive payments). States that rely on the FPA may also be able to rely on this two-part payment approach, although FERC has not rules on the legality of that approach. Importantly, this option is only available to certified QFs (which have the option of self-certifying with FERC).

States that rely on state law (and are subject to the FPA) require FERC clarification of certain precedents before a clear, non-preempted path for feed-in tariff policies is available. A change in FERC precedent could clarify that state-law utility obligations to purchase renewable energy from entities with QF status (20 MW or smaller) are not subject to the PURPA avoided cost cap or subject to FPA filing requirements. If changed, this clarification would allow statelaw feed-in tariff programs similar to those found in Europe: states could mandate utilities to purchase renewable energy at payments higher than utility avoided cost from entities with QF status (20 MW or below) without additional steps or actions. Without a change in existing FERC precedents, the only options that exist are to apply to FERC for (1) contract-by-contract approval that the rate reflects prudent costs and a reasonable rate of return (i.e. cost-based rates), or (2) blanket advance approval for sellers that lack or mitigate market power (i.e. market-based rates).

Because of the multiple legal uncertainties discussed in this report, participants in this policymaking area should consider discussing with FERC informal steps leading to a rulemaking proceeding. Those seeking this action would identify their goals, explain the legal uncertainties impeding those goals, and offer suggestions for removing the uncertainties. A useful outcome to this process would be a series of FERC pronouncements that:

(a) Clarify the law on PURPA preemption and FPA preemption in the various feed-in tariff scenarios discussed in this report;

(b) Create processes for establishing cost-based safe harbors for various technologies, project sizes, and geographic areas, where these safe harbors applied in both the PURPA and FPA context; 
(c) Create a process by which sellers under feed-in tariffs could obtain findings of no market power; and

(d) Evaluate the effects of these modifications after several years.

There are multiple procedural paths to such a FERC rule: workshops, notices of inquiry, notices of proposed rulemaking, and requests for declaratory orders on generic issues or on statespecific or region-specific tariffs. An informal set of conversations on the multiple questions raised by this report would be a useful start.

Finally, Congress always has the authority to revise federal law. While the language in the House-passed American Clean Energy and Security Act of 2009 (see Part III.A above) leaves several key points unclear, Congress could choose to revisit the language and clarify the unclear points described in this report 


\section{Appendix A: \\ Overview of Preemption Analysis}

The preemption doctrine derives from the Supremacy Clause of the Constitution, ${ }^{71}$ which provides:

"This Constitution, and the Laws of the United States which shall be made in Pursuance thereof; and all Treaties made, or which shall be made, under the Authority of the United States, shall be the supreme Law of the Land; and the Judges in every State shall be bound thereby, any Thing in the Constitution or Laws of any State to the contrary notwithstanding."

The United States Supreme Court has summarized the concept:

"The Supremacy Clause provides Congress with the power to preempt state law. Preemption occurs when Congress, in enacting a federal statute, expresses a clear intent to preempt state law, when there is outright or actual conflict between federal and state law, where compliance with both federal and state law is in effect physically impossible, where there is implicit in federal law a barrier to state regulation, where Congress has legislated comprehensively, thus occupying an entire field of regulation and leaving no room for the States to supplement federal law, or where the state law stands as an obstacle to the accomplishment and execution of the full objectives of Congress. ${ }^{72}$

Preemption analysis of a federal statute consists of a structured, multi-step inquiry. The analysis begins with an examination of Congressional intent. ${ }^{73}$ Congress's intent is discerned from the language of the statute, with the assumption that the ordinary meaning of the language accurately expresses the legislative purpose. ${ }^{74}$ Absent clarity in legislative language, preemption analysis next examines the statute's overall framework and legislative history for evidence regarding Congress' intent to preempt. ${ }^{75}$

71 U.S. Const. art. VI, Paragraph 2.

72 Louisiana. Pub. Serv. Comm n. v. FCC, 476 U.S. 355, 368-69 (1986).

73 Medtronic Inc. v. Lohr, 518 U.S. 470, 485-486 (1996) ("The purpose of Congress is the ultimate touchstone in every preemption case.").

74 Park n Fly, Inc. v Dollar Park \& Fly Inc., 469 U.S. 189, 194, 105 S. Ct. 658, 661 (1985).

75 Auburn Hous. Auth. v. Martinez, 277 F.3d 138, 144 (2d Cir. 2002). 
If Congress intended to occupy an entire field of regulation, federal law overrides state law, irrespective of any actual conflict. ${ }^{76}$

Alternatively, preemption analysis might conclude that Congress did not intend to displace state regulation entirely. Where Congress has thus intended shared federal-state regulatory responsibility, preemption occurs only where state law actually conflicts with federal law. ${ }^{77}$ A conflict occurs where either (1) compliance with both the federal and state laws is physically impossible, e.g., where compliance with the state law causes a violation of federal law; ${ }^{78}$ or (2) state law poses an "obstacle" to Congress's purpose. ${ }^{79}$ In situations where federal and state authority conflict, state law must give way.

76 See, e.g., Rice v. Santa Fe Elevator Corp., 331 U.S. 218, 67 S. Ct. 1146 (1947) (finding that the Warehouse Act preempted a state statute, even where no actual conflicts existed, since Congress intended to eliminate dual state-federal regulatory system and assume jurisdiction over entire storage scheme.

77 La. Pub. Serv. Comm n. v. FCC, 476 U.S. at 368-69.

78 Florida Lime \& Avocado Growers, Inc. v. Paul, 373 U.S. 132, 142143, 83 S. Ct. 1210, 1217-18 (1963) ("A holding of federal exclusion of state law is inescapable and requires no inquiry into congressional design where compliance with both federal and state regulations is a physical impossibility for one engaged in interstate commerce.").

79 Hines v. Davidowitz, 312 U.S. 52, 67 (1941) ("Our primary function is to determine whether [a state law] stands as an obstacle to the accomplishment and execution of the full purposes and objectives of Congress."). 


\title{
Appendix B: \\ PURPA Exemptions and Termination of Mandatory Purchase Provisions- Statutes and Regulations
}

\author{
PURPA, as amended by EPAct 2005: Termination of mandatory purchase and sale \\ requirements, 16 U.S.C. $824 a-3(m)$ :
}

(m) Termination of mandatory purchase and sale requirements.

(1) Obligation to purchase. After the date of enactment of this subsection [enacted Aug. $8,2005]$, no electric utility shall be required to enter into a new contract or obligation to purchase electric energy from a qualifying cogeneration facility or a qualifying small power production facility under this section if the Commission finds that the qualifying cogeneration facility or qualifying small power production facility has nondiscriminatory access to-

(A) (i) independently administered, auction-based day ahead and real time wholesale markets for the sale of electric energy; and (ii) wholesale markets for long-term sales of capacity and electric energy; or

(B) (i) transmission and interconnection services that are provided by a Commissionapproved regional transmission entity and administered pursuant to an open access transmission tariff that affords nondiscriminatory treatment to all customers; and (ii) competitive wholesale markets that provide a meaningful opportunity to sell capacity, including long-term and short-term sales, and electric energy, including long-term, shortterm and real-time sales, to buyers other than the utility to which the qualifying facility is interconnected. In determining whether a meaningful opportunity to sell exists, the Commission shall consider, among other factors, evidence of transactions within the relevant market; or

(C) wholesale markets for the sale of capacity and electric energy that are, at a minimum, of comparable competitive quality as markets described in subparagraphs (A) and (B).

(2) Revised purchase and sale obligation for new facilities.

(A) After the date of enactment of this subsection [enacted Aug. 8, 2005], no electric utility shall be required pursuant to this section to enter into a new contract or obligation to purchase from or sell electric energy to a facility that is not an existing qualifying cogeneration facility unless the facility meets the criteria for qualifying cogeneration facilities established by the Commission pursuant to the rulemaking required by subsection (n). 
(B) For the purposes of this paragraph, the term "existing qualifying cogeneration facility" means a facility that-

(i) was a qualifying cogeneration facility on the date of enactment of subsection (m) [enacted Aug. 8, 2005]; or

(ii) had filed with the Commission a notice of self-certification, self recertification or an application for Commission certification under 18 CFR 292.207 prior to the date on which the Commission issues the final rule required by subsection (n).

(3) Commission review. Any electric utility may file an application with the Commission for relief from the mandatory purchase obligation pursuant to this subsection on a service territory-wide basis. Such application shall set forth the factual basis upon which relief is requested and describe why the conditions set forth in subparagraph (A), (B), or (C) of paragraph (1) of this subsection have been met. After notice, including sufficient notice to potentially affected qualifying cogeneration facilities and qualifying small power production facilities, and an opportunity for comment, the Commission shall make a final determination within 90 days of such application regarding whether the conditions set forth in subparagraph (A), (B), or (C) of paragraph (1) have been met.

(4) Reinstatement of obligation to purchase. At any time after the Commission makes a finding under paragraph (3) relieving an electric utility of its obligation to purchase electric energy, a qualifying cogeneration facility, a qualifying small power production facility, a State agency, or any other affected person may apply to the Commission for an order reinstating the electric utility's obligation to purchase electric energy under this section. Such application shall set forth the factual basis upon which the application is based and describe why the conditions set forth in subparagraph (A), (B), or (C) of paragraph (1) of this subsection are no longer met. After notice, including sufficient notice to potentially affected utilities, and opportunity for comment, the Commission shall issue an order within 90 days of such application reinstating the electric utility's obligation to purchase electric energy under this section if the Commission finds that the conditions set forth in subparagraphs (A), (B) or (C) of paragraph (1) which relieved the obligation to purchase, are no longer met.

(5) Obligation to sell. After the date of enactment of this subsection [enacted Aug. 8, 2005], no electric utility shall be required to enter into a new contract or obligation to sell electric energy to a qualifying cogeneration facility or a qualifying small power production facility under this section if the Commission finds that-

(A) competing retail electric suppliers are willing and able to sell and deliver electric energy to the qualifying cogeneration facility or qualifying small power production facility; and 
(B) the electric utility is not required by State law to sell electric energy in its service territory.

FERC Regulations re: termination of obligation to purchase (18 C.F.R. $§ 309$ )

\section{§ 292.309 Termination of obligation to purchase from qualifying facilities.}

(a) After August 8, 2005, an electric utility shall not be required, under this part, to enter into a new contract or obligation to purchase electric energy from a qualifying cogeneration facility or a qualifying small power production facility if the Commission finds that the qualifying cogeneration facility or qualifying small power facility production has nondiscriminatory access to:

(1)(i) Independently administered, auction-based day ahead and real time wholesale markets for the sale of electric energy; and

(ii) Wholesale markets for long-term sales of capacity and electric energy; or

(2)(i) Transmission and interconnection services that are provided by a Commissionapproved regional transmission entity and administered pursuant to an open access transmission tariff that affords nondiscriminatory treatment to all customers; and

(ii) Competitive wholesale markets that provide a meaningful opportunity to sell capacity, including long-term and short-term sales, and electric energy, including longterm, short-term and real-time sales, to buyers other than the utility to which the qualifying facility is interconnected. In determining whether a meaningful opportunity to sell exists, the Commission shall consider, among other factors, evidence of transactions within the relevant market; or

(3) Wholesale markets for the sale of capacity and electric energy that are, at a minimum, of comparable competitive quality as markets described in paragraphs (a)(1) and (a)(2) of this section.

(b) For purposes of $\S 292.309$ (a), a renewal of a contract that expires by its own terms is a "new contract or obligation" without a continuing obligation to purchase under an expired contract.

(c) For purposes of $\S 292.309(a)(1),(2)$ and (3), with the exception of paragraph (d) of this section, there is a rebuttable presumption that a qualifying facility has nondiscriminatory access to the market if it is eligible for service under a Commissionapproved open access transmission tariff or Commission-filed reciprocity tariff, and Commission-approved interconnection rules. If the Commission determines that a market meets the criteria of $\$ 292.309(a)(1)$, (2) or (3), and if a qualifying facility in the relevant market is eligible for service under a Commission-approved open access transmission tariff or Commission-filed reciprocity tariff, a qualifying facility may seek to rebut the presumption of access to the market by demonstrating, inter alia, that it does not have access to the market because of operational characteristics or transmission constraints. 
(d)(1) For purposes of $\S 292.309(a)(1),(2)$, and (3), there is a rebuttable presumption that a qualifying facility with a capacity at or below 20 megawatts does not have nondiscriminatory access to the market.

(2) For purposes of implementing paragraph (d)(1) of this section, the Commission will not be bound by the one-mile standard set forth in $\$ 292.204(\mathrm{a})(2)$.

(e) Midwest Independent Transmission System Operator (Midwest ISO), PJM Interconnection, L.L.C. (PJM), ISO New England, Inc. (ISO-NE), and New York Independent System Operator (NYISO) qualify as markets described in $\$ 292.309(\mathrm{a})(1)(\mathrm{i})$ and (ii), and there is a rebuttable presumption that qualifying facilities with a capacity greater than 20 megawatts have nondiscriminatory access to those markets through Commission-approved open access transmission tariffs and interconnection rules, and that electric utilities that are members of such regional transmission organizations or independent system operators (RTO/ISOs) should be relieved of the obligation to purchase electric energy from the qualifying facilities. A qualifying facility may seek to rebut this presumption by demonstrating, inter alia, that:

(1) The qualifying facility has certain operational characteristics that effectively prevent the qualifying facility's participation in a market; or

(2) The qualifying facility lacks access to markets due to transmission constraints. The qualifying facility may show that it is located in an area where persistent transmission constraints in effect cause the qualifying facility not to have access to markets outside a persistently congested area to sell the qualifying facility output or capacity.

(f) The Electric Reliability Council of Texas (ERCOT) qualifies as a market described in $\$ 292.309(\mathrm{a})(3)$, and there is a rebuttable presumption that qualifying facilities with a capacity greater than 20 megawatts have nondiscriminatory access to that market through Public Utility Commission of Texas (PUCT) approved open access protocols, and that electric utilities that operate within ERCOT should be relieved of the obligation to purchase electric energy from the qualifying facilities. A qualifying facility may seek to rebut this presumption by demonstrating, inter alia, that:

(1) The qualifying facility has certain operational characteristics that effectively prevent the qualifying facility's participation in a market; or

(2) The qualifying facility lacks access to markets due to transmission constraints. The qualifying facility may show that it is located in an area where persistent transmission constraints in effect cause the qualifying facility not to have access to markets outside a persistently congested area to sell the qualifying facility output or capacity.

(g) The California Independent System Operator and Southwest Power Pool, Inc. satisfy the criteria of $\S 292.309(a)(2)(i)$.

(h) No electric utility shall be required, under this part, to enter into a new contract or obligation to purchase from or sell electric energy to a facility that is not an existing 
qualifying cogeneration facility unless the facility meets the criteria for new qualifying cogeneration facilities established by the Commission in $\$ 292.205$.

(i) For purposes of $\$ 292.309(\mathrm{~h})$, an "existing qualifying cogeneration facility" is a facility that:

(1) Was a qualifying cogeneration facility on or before August 8, 2005; or

(2) Had filed with the Commission a notice of self-certification or self-recertification, or an application for Commission certification, under §292.207 prior to February 2, 2006.

(j) For purposes of $\$ 292.309(\mathrm{~h})$, a "new qualifying cogeneration facility" is a facility that satisfies the criteria for qualifying cogeneration facilities pursuant to $§ 292.205$.

[Order 688, 71 FR 64372, Nov. 1, 2006; 71 FR 75662, Dec. 18, 2006]

\section{Exemptions from Section 205 of FPA}

\section{§ 292.601 Exemption to qualifying facilities from the Federal Power Act.}

(a) Applicability. This section applies to qualifying facilities, other than those described in paragraph (b) of this section.

(b) Exclusion. This section does not apply to a qualifying small power production facility with a power production capacity that exceeds 30 megawatts, if such facility uses any primary energy source other than geothermal resources.

(c) General rule. Any qualifying facility described in paragraph (a) of this section shall be exempt from all sections of the Federal Power Act, except:

(1) Sections 205 and 206; however, sales of energy or capacity made by qualifying facilities $20 \mathrm{MW}$ or smaller, or made pursuant to a contract executed on or before March 17,2006 or made pursuant to a state regulatory authority's implementation of section 210 the Public Utility Regulatory Policies Act of 1978, 16 U.S.C. 824a-1, shall be exempt from scrutiny under sections 205 and 206;

(2) Section 1-18, and 21-30;

(3) Sections 202(c), 210, 211, 212, 213, 214, 215, 220, 221 and 222;

(4) Sections 305(c); and

(5) Any necessary enforcement provision of part III of the Federal Power Act (including but not limited to sections 306, 307, 308, 309, 314, 315, 316 and 316A) with regard to the sections listed in paragraphs (c)(1), (2), (3) and (4) of this section.

(Energy Security Act, Pub. L. 96-294, 94 Stat. 611 (1980) Public Utility Regulatory Policies Act of 1978, 16 U.S.C. 2601, et seq., Energy Supply and Environmental 
Coordination Act, 15 U.S.C. 791, et seq., Federal Power Act, as amended, 16 U.S.C. 792 et seq., Department of Energy Organization Act, 42 U.S.C. 7101, et seq. ; E.O. 12009, 42 FR 46267)

[Order 135, 46 FR 19232, Mar. 30, 1981, as amended by Order 569, 59 FR 40470, Aug. 9, 1994; Order 671, 71 FR 7868, Feb. 15, 2006; 72 FR 29063, May 24, 2007] 
PLEASE DO NOT RETURN YOUR FORM TO THE ABOVE ORGANIZATION.

4. TITLE AND SUBTITLE
Renewable Energy Prices in State-Level Feed-in Tariffs: Federal

Law Constraints and Possible Solutions 5a. CONTRACT NUMBER

DE-AC36-08-GO28308

5b. GRANT NUMBER

5c. PROGRAM ELEMENT NUMBER

5d. PROJECT NUMBER

NREL/TP-6A2-47408

5e. TASK NUMBER

PVC9.9720

5f. WORK UNIT NUMBER
7. PERFORMING ORGANIZATION NAME(S) AND ADDRESS(ES)

National Renewable Energy Laboratory

1617 Cole Blvd.

Golden, CO 80401-3393

9. SPONSORING/MONITORING AGENCY NAME(S) AND ADDRESS(ES)
8. PERFORMING ORGANIZATION REPORT NUMBER

NREL/TP-6A2-47408

10. SPONSOR/MONITOR'S ACRONYM(S) NREL

11. SPONSORING/MONITORING AGENCY REPORT NUMBER

12. DISTRIBUTION AVAILABILITY STATEMENT

National Technical Information Service

U.S. Department of Commerce

5285 Port Royal Road

Springfield, VA 22161

\section{SUPPLEMENTARY NOTES}

\section{ABSTRACT (Maximum 200 Words)}

State legislatures and state utility commissions trying to attract renewable energy projects are considering feed-in tariffs, which obligate retail utilities to purchase electricity from renewable producers under standard arrangements specifying prices, terms, and conditions. The use of feed-in tariffs simplifies the purchase process, provides revenue certainty to generators, and reduces the cost of financing generating projects. However, some argue that federal law_including the Public Utility Regulatory Policies Act of 1978 (PURPA) and the Federal Power Act of 1935 (FPA) - constrain state-level feed-in tariffs. This report seeks to reduce the legal uncertainties for states contemplating feed-in tariffs by explaining the constraints imposed by federal statutes. It describes the federal constraints, identifies transaction categories that are free of those constraints, and offers ways for state and federal policymakers to interpret or modify existing law to remove or reduce these constraints. This report proposes ways to revise these federal statutes. It creates a broad working definition of a state-level feed-in tariff. Given this definition, this report concludes there are paths to non-preempted, state-level feed-in tariffs under current federal law.

15. SUBJECT TERMS

feed-in tariffs; FIT; renewable electricity; renewable energy; electricity sales; electricity purchases; financing electricity generating projects; states; state legislatures; state utility commissions; state policymakers; federal law; federal statutes; the Public Utility Regulatory Policies Act of 1978; PURPA; Federal Power Act of 1935; FPA

\begin{tabular}{|c|c|c|}
\hline $\begin{array}{l}\text { a. REPORT } \\
\text { Unclassified }\end{array}$ & $\begin{array}{l}\text { b. ABSTRACT } \\
\text { Unclassified }\end{array}$ & $\begin{array}{l}\text { c. THIS PAGE } \\
\text { Unclassified }\end{array}$ \\
\hline
\end{tabular}

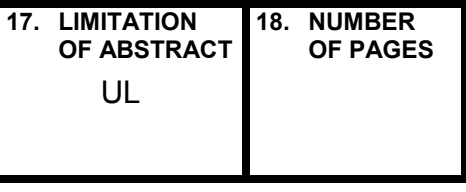

19a. NAME OF RESPONSIBLE PERSON

19b. TELEPHONE NUMBER (Include area code) 